\title{
Zabytkowe dzwony kościelne na terenie diecezji kieleckiej. Warsztaty i twórcy
}

Podejmując badania nad niniejszym zagadnieniem, nie sadziłam, że nastręcza mi one tak wiele trudności. Dotyczy to zwłaszcza ustalenia faktycznej liczby zachowanych obiektów. Wojewódzki Urząd Ochrony Zabytków w Kielcach nie dysponuje bowiem aktualnym wykazem zabytkowych dzwonów $z$ obszaru województwa świętokrzyskiego ${ }^{1}$, a pracujący na parafii księża nie zawsze maja na ten temat wystraczajaca wiedzę (lub po prostu nie wykazuja chęci do współpracy). Z kolei warunki lokalne (np. utrudnione wejście na dzwonnicę, wysoko zawieszone dzwony) w wielu przypadkach uniemożliwiaja weryfikację danych w terenie. Na podstawie dostępnej literatury przedmiotu ${ }^{2}$, materiałów gromadzonych

* Wydział Filozoficzno-Historyczny, Instytut Historii, Katedra Historii Nowożytnej.

1 Ostatni taki spis, obejmujący tereny środkowej i północnej Małopolski, został sporzadzony w 1985 r. przez W. Kowalskiego. Maszynopis tekstu przechowuje Wojewódzki Urząd Ochrony Zabytków [dalej: WUOZ] w Kielcach.

2 Mam tu na myśli głównie prace niestrudzonego badacza dziejów kościelnych, ks. J. Wiśniewskiego, jak również kolejne zeszyty wielotomowego Katalogu zabytków sztuki $w$ Polsce i Corpus Inscriptionum Poloniae. Por. J. W i ś n i e w s k i, Dekanat miechowski, Radom 1917, reprint Kielce 2000; i d e m, Dekanat konecki, Radom 1913, reprint Kielce 2000; i d e m, Dekanat opatowski, Radom 1917, reprint Kielce 2000; idem, Dekanat iłżecki, Radom 1909-1911, reprint Kielce 2000; i d e m, Historyczny opis kościołów, miast, zabytków i pamiatek $w$ Pińczow skiem, Skalbmierskiem i Wiślickiem, Mariówka 1927, reprint Kielce 2000; i d e m, Historyczny opis kościołów, miast, zabytków i pamiątek w Stopnickiem, Mariówka 1929, reprint Kielce 2000; i d e m, Historyczny opis kościołów, miast, zabytków i pamiatek $w$ Jędrzejowskiem, Mariówka 1930, reprint Kielce 2000; i d e m, Historyczny opis kościołów, miast, zabytków i pamiątek $w$ powiecie włoszczowskim, [Mariówka] 1932, reprint Kielce 2000; i d e m, Historyczny opis kościołów, miast, zabytków i pamiątek w Olkuskiem, Mariówka 1933, reprint Kielce 2000; Katalogu zabytków sztuki w Polsce [dalej: Katalog zabytków], t. I (Województwo krakow- 
w kieleckim Archiwum Diecezjalnym, Wojewódzkim Urzędzie Ochrony Zabytków w Kielcach i Krakowie, delegaturze tego pierwszego w Sandomierzu, jak również przeprowadzonych częściowo badań w terenie można stwierdzić, że od rekwizycji i zniszczeń wojennych udało się ocalić na interesującym nas obszarze co najmniej 118 dzwonów odlanych przed $1900 \mathrm{r}$. W tej liczbie jest 16 dzwonów $z$ XIV-XV w., $18 \mathrm{z}$ wieku XVI, $24 \mathrm{z}$ kolejnego stulecia, $42 \mathrm{z}$ wieku XVIII oraz $14 \mathrm{z}$ wieku XIX ${ }^{3}$. W czterech przypadkach nie udało się ustalić czasu powstania instrumentu ${ }^{4}$.

Spośród owych 118 dzwonów i sygnaturek powstałych w XIVXIX w. jedynie 41 to instrumenty sygnowane imieniem, nazwiskiem rzemieślnika, siedzibą jego warsztatu. Autorstwo kolejnych sześciu udało się ustalić dzięki literaturze przedmiotu i badaniom porównawczym ${ }^{5}$. Najstarszy dzwon opatrzony sygnaturką autorską

skie), red. J. Szablowski, z. 8 (Powiat miechowski), oprac. Z. Boczkowska, Warszawa 1953; z. 12 (Powiat olkuski), oprac. K. Kutrzebianka, Warszawa 1953; Katalog zabytków, t. III (Województwo kieleckie), red. J.Z. Łoziński i B. Wolff, z. 1 (Powiat buski), oprac. K. Kutrzebianka, Warszawa 1957; z. 2 (Powiat iłżecki), oprac. O. Puciata i Z. Świechowski, Warszawa 1957; z. 3 (Powiat jędrzejowski), oprac. T. Przypkowski, Warszawa 1957; z. 4 (Powiat kielecki), oprac. T. Przypkowski, Warszawa 1957; z. 5 (Powiat konecki), oprac. M. Kwiczala i inni, Warszawa 1958; z. 6 (Powiat kozienicki), oprac. M. Kwiczala i inni, Warszawa 1958; z. 7 (Powiat opatowski), oprac. K. Kutrzebianka i inni, Warszawa 1959; z. 8 (Powiat opoczyński), oprac. zbiorowe, Warszawa 1958; z. 9 (Powiat pińczowski), oprac. K. Kutrzebianka, J.Z. Łoziński i B. Wolff, Warszawa 1961; z. 10 (Powiat radomski), oprac. K. Szczepkowska, E. Krygier i J.Z. Łoziński, Warszawa 1961; z. 11 (Powiat sandomierski), oprac. J.Z. Łoziński i T. Przypkowski, Warszawa 1962; z. 12 (Powiat włoszczowski), oprac. T. Przypkowski, J.Z. Łoziński i B. Wolff, Warszawa 1966; Corpus inscriptionum Poloniae, t. I (Województwo kieleckie), red. J. Szymański [dalej: CIP], z. 1 (Miasto Kielce i powiat kielecki), wydała, wstępem i komentarzem opatrzyła B. Trelińska, Kielce 1975; z. 2 (Jędrzejów i region jędrzejowski), wydała, wstępem i komentarzem opatrzyła B. Trelińska, Kielce 1978; z. 3 (Busko-Zdrój i region), wydała, wstępem i komentarzem opatrzyła U. Zgorzelska, Kielce 1980; z. 4 (Miechów i Pińczów wraz z regionem), wydała, wstępem i komentarzem opatrzyła B. Trelińska, Kielce 1983; z. 5 (Włoszczowa, Końskie i Ostrowiec Świętokrzyski z regionem), wydał, wstępem i komentarzem opatrzył M. Janik, Kielce 1986.

3 Obliczenia własne na podstawie publikowanych i niepublikowanych materiałów o charakterze ewidencyjnym. W przypadku dzwonów przelewanych wzięto pod uwage datę pierwszego odlewu, o ile została ona uwidoczniona na instrumencie.

4 Mowa tu o dzwonach z Małogoszcza i Dzierążni (bez inskrypcji i dekoracji), sygnaturce zawieszonej na wieży kościoła cystersów w Jędrzejowie (XVIII w.?) oraz sygnaturce w Irzadzach.

5 Instrumenty $z$ Małogoszcza (1655), Skalbmierza (1765), Słomnik (pocz. XVIII w.), Miechowa (1749, 1750) oraz Nasiechowic (1873). 
wykonany został w 1557 r. dla kościoła parafialnego w Zagości (pow. pińczowski). Jego twórca jest pochodzący z Brna Morawskiego mistrz ludwisarski Szymon Nauwitz (Hauwicz, Hawicz), od 1543 r. związany głównie $z$ Krakowem, gdzie pełnił funkcję kierownika odlewni dział królewskich6. Oprócz armat i innych przedmiotów wykonywanych na użytek dworu Nauwitz odlewał także dzwony dla kościołów podkrakowskich i $z$ terenu Małopolski, w tym wspomniany dzwon $z$ Zagości. Parament ten zdobi na szyi łacińska inskrypcja: „Si Deus nobiscum quis contra nos. Christus Rex fortis venit in pace". Poniżej widnieje data odlewu oraz sygnatura twórcy („Simon Nauwitz me fecit”) 7 .

Z wieku XVII pochodza dwa zabytki, które można powiąać $z$ konkretnym rzemieślnikiem. Mowa tu o instrumentach zawieszonych w wolno stojącej dzwonnicy przy kościele pw. Wniebowzięcia Najświętszej Marii Panny w Małogoszczu (pow. jędrzejowski), ulanych w 1655 r. w warsztacie jednego mistrza ludwisarskiego Benedykta Briota (vel Briotta, Briosta) z Lotaryngii, który zapewne był tzw. ludwisarzem wędrownym ${ }^{8}$. Szyję dużego dzwonu zdobi fryz ze stylizowanych lilii heraldycznych. Poniżej, w dwóch pasach, biegnie majuskułowa sentencja w języku łacińskim: „LAUDATE DOMINUM QUONIAM BONUS EST PSALMUS DEO NOSTRO SIT JUCUNDA DECORAQUE LAUDATIO / PSAL[MUS] CXLVI” („Dobrze jest grać naszemu Bogu, wdzięcznie jest nucić pieść pochwalną, Ps $146,1[147,1])$, rok odlewu i sygnaturka mistrza, ujęte od dołu bogatym ornamentem roślinnym. Na płaszczu znajdują się plakietki figuralne ukazujące Matkę Boską $z$ Dzieciątkiem na półksiężycu (w typie Immaculaty), św. Mikołaja i Pana Jezusa na krzy-

6 Więcej na temat S. Nauwitza i jego działalności por. I. Grabow ska, Z. W e n ze 1- H o m e cka, Hauwicz Szymon, [w:] Polski słownik biograficzny [dalej: $P S B$ ], t. IX, Wrocław-Kraków-Warszawa 1960, s. 320; K. G i e r d z i e j e w s k i, Zarys dziejów odlewnictwa polskiego, Stalinogrów (Katowice) 1954, s. 97.

7 Cyt. za: W. S i a r k o w s k i, Dzwony w guberni kieleckiej (rzecz archeologiczno-historyczna), Warszawa 1878, s. 32. Dziełem Nauwitza był także dzwon z kościoła pw. św. Jana Chrzciciela w Gnojnie (pow. buski), ulany w 1559 r., zarekwirowany przez Niemców w czasie II wojny światowej. Widniała na nim trójwierszowa inskrypcja: „SIMON HAVICZ PRUNENSIS AUXILIO DIVINO ME FECIT”, a po przeciwnej stronie rok odlewu i wizerunek Chrystusa na krzyżu. Por. ibidem, s. 32, przyp. 1; J. Wiśniew ski, Historyczny opis kościołów [...] w Stopnickiem..., s. 91; J. Ko ł a c z k ow s ki, Wiadomości tyczace się przemysłu $i$ sztuki $w$ dawnej Polsce, Kraków 1888, s. 400, 404.

8 K. Gie rdziejew s ki, op. cit., s. 129; W. Kow als ki, Benedykt Briott Lotaryńczyk, „Studia Kieleckie” 1984, nr 3 (43), s. 141-149. 
żu, a w kilku miejscach (na czapie i pod krucyfiksem) rozmieszczono odlewy liści, najpewniej wierzby (il. 1-2). Szyję mniejszego dzwonu dekoruje podwójny fryz skomponowany $z$ fleur-de-lis (w odbiciu lustrzanym). Pomiędzy fryzami widnieje gładki pas wypełniony inskrypcja - lekko zmodyfikowanym cytatem z Psalmu 65,1-2 (66,1-2): „IUBILATE DEO OMNIS TERRA, PSALMUI DICIET NOMINI EI[US], GLORIAM EI[US]” („Sławcie Boga $z$ radościa wszystkie ziemie, opiewajcie chwałę Jego imienia, cześć Jemu oddajcie") 9 , a na płaszczu wizerunki Maryi Niepokalanej i Chrystusa Ukrzyżowanego (il. 3-4)10. Warto nadmienić, że do czasu II wojny światowej na terenie diecezji kieleckiej znajdowały się jeszcze cztery inne dzwony tego rzemieślnika, wykonane dla kościołów w Lelowie (1642 r.), Szydłowie (1643 r., przelany w 1903 r.) i Proszowicach $\left(1652,1657\right.$ r.) ${ }^{11}$. Niestety, pierwszy $z$ nich stopił się w czasie pożaru świątyni po nalocie niemieckiego Luftwaffe we wrześniu 1939 r., pozostałe natomiast padły łupem rekwizycji wojennych ${ }^{12}$.

$Z$ kolejnego stulecia zachowało się ponad 30 sygnowanych paramentów. Wśród nich dominują dzwony pochodzące ze słynnych w tym czasie ludwisarni gdańskich Wittwercków, Karola Gotfryda Anthony'ego, jak również z nie mniej aktywnych - szczególnie

9 Napis częściowo dziś zatarty, odlany niestarannie, $z$ błędami powstałymi na skutek przestawienia liter w wyrazie (np. diciet zamiast dicite).

10 Cyt. za: J. Wiśn niew ski, Historyczny opis kościołów [...] w Jędrzejowskiem..., s. 13. Por. też W. Sia rkow ski, op. cit., s. 38; J. Kołaczkow ski, op. cit., s. 400, 409; C. H a d a mik, D. Kalin a, E. Tr a czyńs ki, Miasto i gmina Małogoszcz [seria: Dzieje i zabytki małych ojczyzn, red. R. Mirowski], Kielce 2006, s. 191-192; Katalog zabytków, t. III, z. 3, s. 20; CIP, z. 2, s. 120-121, nr 123 i 124. W dwóch ostatnich pracach odnotowano tylko jeden dzwon odlany przez Briota dla kościoła w Małogoszczu. Wiadomo jednak $z$ autopsji, że zachowały się oba te zabytki, i to w dobrym stanie.

11 J. Kołaczkowski, op. cit., s. 400, 408, 416; K. Gierdziejews ki, op. cit., s. 129; J. Wiśniew ski, Historyczny opis kościołów [...] w powiecie włoszczowskim..., s. 156; i d e m, Historyczny opis kościołów, miast [...] w Stopnickiem..., s. 304; i d e m, Dekanat miechowski..., s. 186.

12 Por. M. Ka rko c ha, Dzwony kościelne utracone $w$ czasie II wojny światowej z terenu diecezji kieleckiej. Przyczynek do zagadnienia, „Przegląd Nauk Historycznych" 2014, R. XIII, nr 2, s. 106, przyp. 41; e a d e m, Straty materialne Kościoła katolickiego na terenie diecezji kieleckiej w czasie II wojny światowej, „Przegląd Nauk Historycznych" 2015, R. XIV, nr 1, s. 103, 105; Straty wojenne. Zabytkowe dzwony utracone $w$ latach 1939-1945 w granicach Polski po 1945, t. I (Województwo krakowskie i rzeszowskie), oprac. J. Gołos, A. Kasprzak-Miler, „Polskie Dziedzictwo Kulturalne”, Seria A, „Straty Kultury Polskiej”, Poznań 2000, s. 275-276 (tu wprawdzie odnotowano oba proszowickie dzwony, nie powiąano ich jednak $z$ konkretnym rzemieślnikiem). 


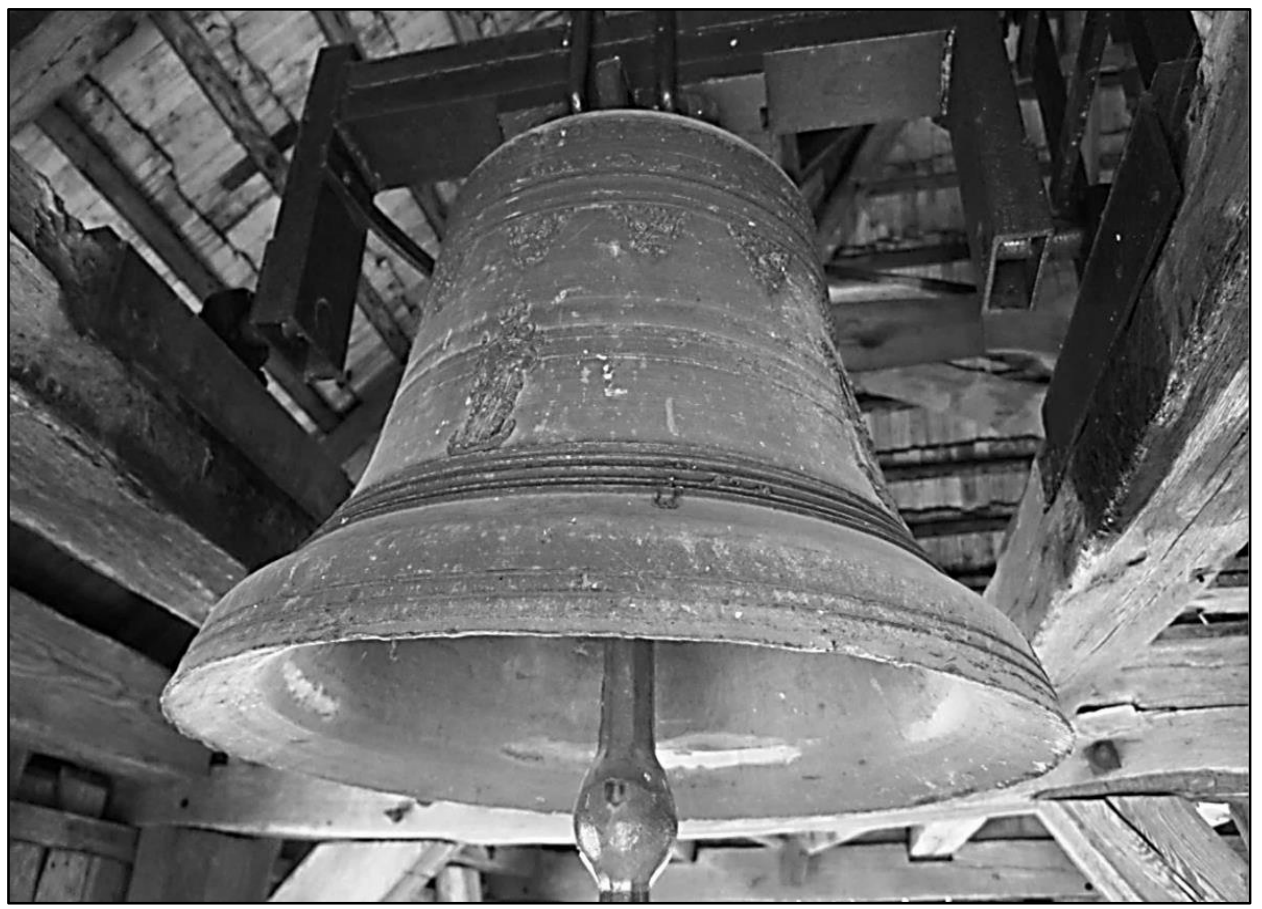

1. Duży dzwon z kościoła pw. Wniebowzięcia Najświętszej Marii Panny w Małogoszczu, Benedykt Briot $z$ Lotaryngii, 1655 r. ${ }^{13}$

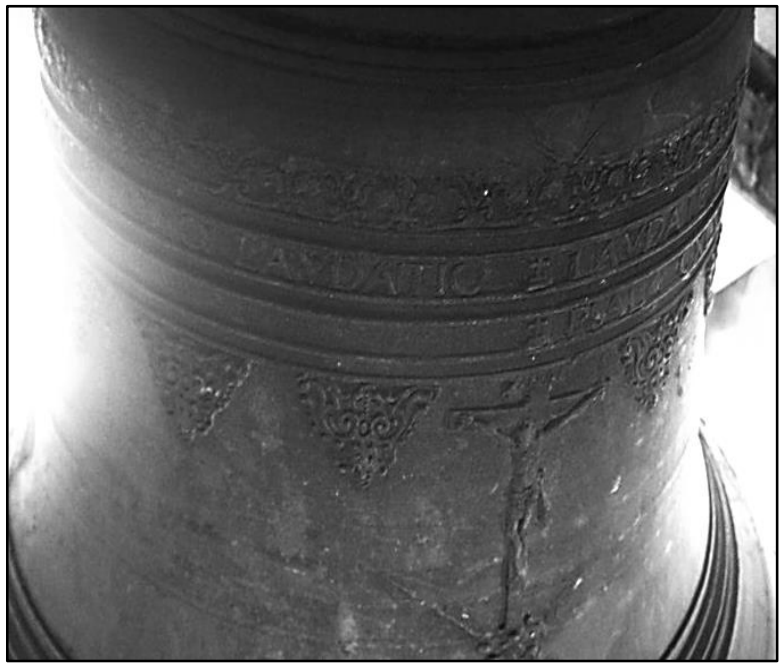

2. Fragment inskrypcji i dekoracji na dużym dzwonie $z$ kościoła parafialnego w Małogoszczu z 1655 r.

13 Ilustracje dzwonów, o ile nie odnotowano inaczej, mojego autorstwa. 


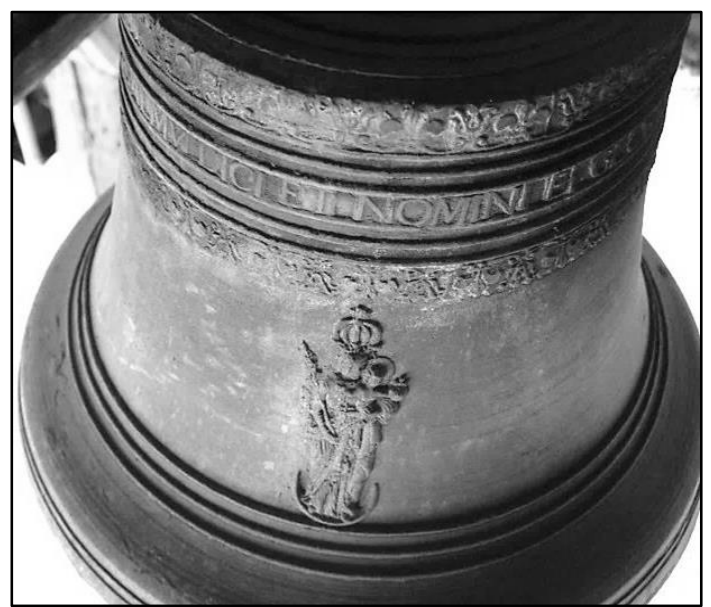

3. Dzwon „średni” $z$ kościoła parafialnego w Małogoszczu, Benedykt Briot $z$ Lotaryngii, 1655 r.

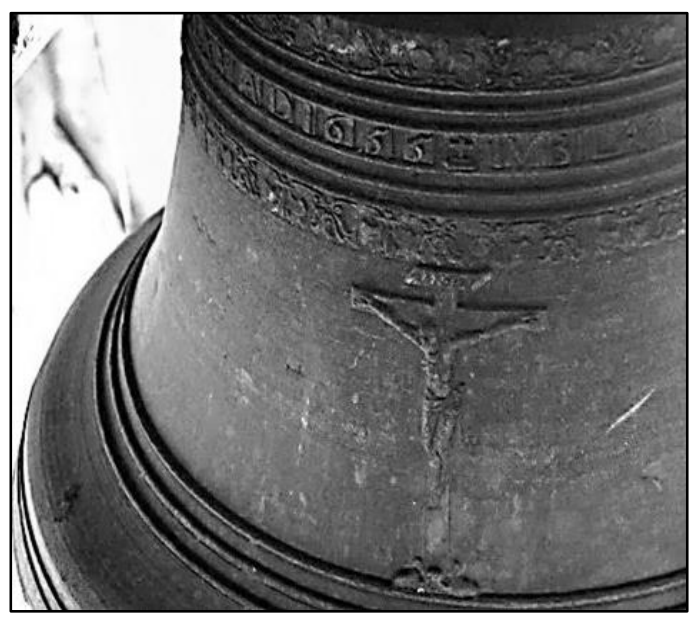

4. Dzwon „średni” z Małogoszczu, Benedykt Briot $z$ Lotaryngii, 1655 r., fragment dekoracji płaszcza $z$ plakietka Chrystusa Ukrzyżowanego

w drugiej połowie XVIII w. - warsztatów krakowskich Weidnerów, Ignacego Huflauera czy Baltazara Ruszkowskiego. Przegląd zabytków $z$ tego okresu wypada rozpocząc od chronologicznie najwcześniejszego, odlanego w 1702 r., dzwonu $z$ kościoła parafialnego w Zagości. Jest on wspólnym dziełem wrocławskich ludwisarzy braci Sebastiana i Zygmunta Goetzów (także Getz, Götz, Götte, Goize) ${ }^{14}$, reprezentujacych najpewniej piąte już pokolenie tej zna-

14 Sebastian (zm. 1719) i Zygmunt (zm. 1714) - określani w literaturze roboczo jako Sebastian II i Zygmunt II - byli synami Zygmunta I (zm. 1703), a wnukami Sebastiana I (ok. 1597-1660). Ten ostatni pozostawił po sobie prawie 20 znanych dziś dzwonów, ulanych dla kościołów Wrocławia i z terenów Ślaska. Więcej na temat tej rodziny odlewniczej i jej działalności por. P. Os z c z a now - 
nej rodziny rzemieślniczej, która w XVI i XVII stuleciu bez mała zmonopolizowała produkcję (przede wszystkim dzwonów) w stolicy Śląska. Na zabytku znajdują się wotywna inskrypcja wyrażająca cześć Bogu Wszechmogącemu, Najświętszej Marii Pannie i św. Janowi Chrzcicielowi - patronowi świątyni, wymieniająca także fundatorów, Marcina i Zofię Sewerów, skądinąd nieznanych, oraz sygnaturka odlewnicza: „SIGISMVND ET SEBASTIAN / GOETZ ME FECIT / WRATIISLAVIAE”. Poniżej umieszczono napis: „LAUDO DEUM VERUM, PLEBEM VOCO, CONGREGO CLERUM, DEFUNCTOS PLORO, PESTEM FUGO, FESTA DECORO” („Wielbię Boga prawdziwego, zwołuję lud, gromadzę duchowieństwo, opłakuję zmarłych, odpędzam zarazę, przyozdabiam święta"), co sugeruje, że instrument mógł być używany głównie w celach apotropaicznych i do dzwonienia w czasie pogrzebów ${ }^{15}$.

W kościele pw. Matki Boskiej Różańcowej w Nagłowicach zachował się zespół dwóch dzwonów wykonanych w gdańskim warsztacie Wittwercków. Na większym widnieje sentencja $z$ Psalmu 112,2 (113,2): „SIT NOMEN DOMINI BENEDICTUM” („Niech imię Pańskie będzie błogosławione"), rok odlewu i sygnaturka ludwisarza („ME FECIT MICHAEL WITTWERCK GEDANI ANNO 1721”). Na mniejszym, pochodzacym z 1740 r., umieszczono $z$ kolei inskrypcję: „SOLI DEO GLORIA” („Samemu Bogu cześć i chwała”), zaczerpnięta $z$ Pierwszego Listu do Tymoteusza $\left(1\right.$ Tym. 1,17) ${ }^{16}$. Praca ta sygnowana jest jedynie literka „W”, co utrudnia powiazanie jej $z$ konkretnym autorem. To, że wyszła ona $z$ warsztatu Wittwercków, nie ulega najmniejszej wątpliwości. Otwarte pozostaje jednak pytanie, który przedstawiciel wzmiankowanej rodziny ludwisarskiej jest jej twórcą. W grę wchodzą dwaj synowie Michała Wittwercka (1674-1732): starszy Jan Gotfryd (1711-1783), czynny w latach 1733-1737 (niewykluczone jednak, że także w późniejszym czasie),

s ki, Rodzina Götzów - z historii wrocławskiego ludwisarstwa. Wstęp do badań, [w:] Ludwisarstw w Polsce. Materiały z III Sesji Naukowej z cyklu „Rzemiosło artystyczne i wzornictwo w Polsce”, zorganizowanej przez Muzeum Okręgowe w Toruniu oraz Toruński Oddział Stowarzyszenia Historyków Sztuki, w dniach 89 listopada 2002 roku, Toruń 2003, s. 75-77.

15 Por. CIP, t. I, z. 4, s. 206, nr 286. Nieco inny układ inskrypcji podaje J. W iśn nie w ski, Historyczny opis kościołów [...] w Pinczowskiem, Skalbmierskiem $i$ Wiślickiem..., s. 477. O dzwonach „opłakujących zmarłych” por. M. Roż e k, Mortuos plango, [w:] i d e m, Sekrety Krakowa: ludzie, zdarzenia, idee, Kraków 2003, s. 100-106.

16 J. W iśn niewski, Historyczny opis kościołów [...] w Jędrzejowskiem..., s. 311 ; CIP, t. I, z. 2, s. 143-144, nr 157 i 158. 
oraz młodszy Emanuel (1719-1787), odlewający dzwony już w roku 1735. Obaj bowiem stosowali podobne sentencje w inskrypcjach, dekorację ornamentalną i figuralną. Być może pogłębiona kwerenda archiwalna pozwoli w przyszłości rozstrzygnąc kwestię autorstwa tego paramentu. Na obecnym etapie badań jest to po prostu niemożliwe ${ }^{17}$.

Dziełem Michała Wittwercka jest także niewielki dzwon sygnaturkowy z kościoła parafialnego w Piotrkowicach Stopnickich (pow. kielecki), ulany w roku 1732, więc na krótko przed śmiercia tego mistrza ludwisarskiego (il. 5). Na szyi paramentu znajduje się inskrypcja poświadczeniowa: „ME FECIT M[ICHAEL] W[ITTWERCK] AN[N]O 1732", zestawiona $z$ popularna sentencja „SOLI DEO GLORIA". Poniżej widnieje pas ornamentu utworzony ze zwisających liści akantu18.

Wzmiankowany Emanuel Wittwerck jest autorem dzwonu wykonanego dla klasztoru cystersów w Jędrzejowie, ważącego ok. $700 \mathrm{~kg}$, sprawionego na pamiątkę beatyfikacji bł. Wincentego Kadłubka (il. 6) ${ }^{19}$. Szyję instrumentu obiega podwójny pas bogatych roślinnych ornamentów, pomiędzy którymi znajduje się gładka wstęga $z$ napisem: „LAUDATUR JESUS CHRISTUS. ME FECIT IMMANUEL WIT[T]WER[CK] GEDANI ANNO 1765". Na płaszczu widnieje Oko Opatrzności w promienistej glorii, zamknięte w trójkacie, a pod nim napis: „HAEC CAMPANA DIVINA PROVIDENTIA REFUSA"20.

17 Problemu tego nie rozstrzygnęła w sposób jednoznaczny E. Wróblewska, autorka najnowszej monografii dotyczącej Wittwercków, która raz wiąże ów dzwon ze starszym synem Michaela, a raz $z$ młodszym $z$ braci. Por. id e m, Ludwisarnie Benningków, Wittwercków i Anthonych: studium $z$ dziejów gdańskiego cechu odlewniczego, Warszawa 1999, s. 68, 71.

18 Katalog zabytków, t. III, z. 1, s. 55; J. W iś n i e w s k i, Historyczny opis kościołów [...] w Stopnickiem..., s. 214; E. W r ó blew s k a, op. cit., s. 58, 60 (oraz katalog na s. 167). Kilka lat temu dzwon spadł i uległ uszkodzeniu (informacja uzyskana od proboszcza parafii, o. Leszka Stańczewskiego, któremu składam w tym miejscu podziękowanie).

19 Archiwum Diecezjalne w Kielcach [dalej: ADK], Akta kurialne ogólne. Sprawozdania o dzwonach kościelnych zabranych przez władze niemieckie 19411947, sygn. OD-11/4, k. 68, 69. A.A. D u d e k (Jędrzejów. Archiopactwo cystersów, Warszawa 1991, s. 56) omyłkowo przypisał autorstwo tego paramentu Ernestowi Fryderykowi Kochowi. Podał jednak dokładna wage dzwonu - $670 \mathrm{~kg}$.

20 Cyt. za: J. Wiśn ie w ski, Historyczny opis kościołów [...] w Jędrzejowskiem..., s. 60. Dzwon ten pękł w 1890 r. Przetopiono go w okresie międzywojennym (1929 r.) w ludwisarni Karola Szwabe w Bielsku-Białej, staraniem proboszcza parafii, ks. Stanisława Marchewki. Por. A.A. Dudek, op. cit., s. 56-56. Nad- 


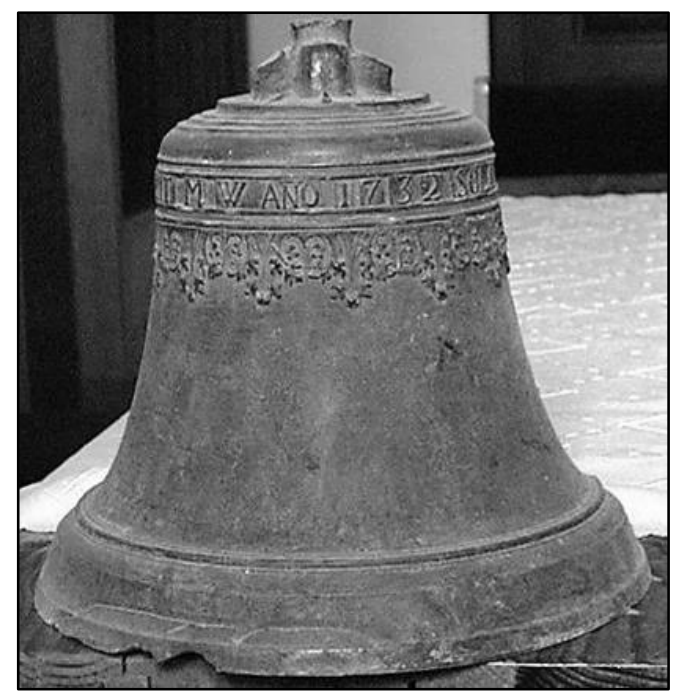

5. Piotrkowice Stopnickie, kościół pw. Zwiastowania NMP, św. św. Franciszka i Marcina, sygnaturka Michała Wittwercka $z \quad 1732$ r. (ze zbiorów Archiwum Parafialnego w Piotrkowicach)

Dwa inne dzwony wykonane dla cystersów jędrzejowskich (il. 7-9), o wadze ok. 2000 i $1000 \mathrm{~kg}$, zostały odlane w 1768 r. przez gdańskiego ludwisarza Ernesta Fryderyka Kocha (zm. 1797) ${ }^{21}$. Podobnie jak wcześniejszy, upamiętniają one beatyfikację bł. Wincentego Kadłubka. Szyję większego dzwonu obiega podwójny pas bogatych rokokowych ornamentów, pomiędzy którymi widnieje wykonana kapitała humanistyczną, wotywno-poświadczeniowa inskrypcja: „LAUDETUR JESUS CHRISTUS ME FECIT FRIEDERICH KOCH GEDANI ANNO 1768". W centralnej części płaszcza umieszczono owalna plakietkę wyobrażająca bł. W. Kadłubka w czasie modlitwy, klęczącego obok stołu, na którym znajdują się

mieńmy w tym miejscu, że $z$ warsztatu Emanuela Wittwercka wyszedł także instrument przeznaczony dla kościoła w Cudzynowicach (pow. kazimierski), datowany na 1759 r., opatrzony sentencja $z$ Psalmu 112,2 („SIT NOMEN DOMINI BENEDICTVM”) oraz sygnaturką: „ME FECIT IMMANVEL WITTWERCK GEDANI ANNO 1759". Zabytek ten szczęśliwie uniknął rekwizycji na cele militarne w czasie obu wojen światowych. Jeszcze na początku lat osiemdziesiątych wisiał w dzwonnicy i został zinwentaryzowany. Jego dalsze losy nie są znane. Być może uległ uszkodzeniu i został przelany. Nie wspomina o nim autor najnowszej monografii Cudzynowic S. Czuba, który odnotowuje jedynie trzy dzwony z 1981 r., wykonane przez firmę Felczyńskich w Przemyślu. Por. CIP, t. I, z. 4, s. 53, nr 28; J. Wi śnie wski, Historyczny opis kościołów [...] w Pinczowskiem, Skalbmierskiem $i$ Wiślickiem..., s. 47; S. C z u b a, Cudzynowice 1326-2001. Od Cudzinowic do Cudzynowic. Zarys dziejów i obyczajów, Gdynia 2003; rozmowa z proboszczem parafii Cudzynowice, ks. W. Pawlikiem, z 20 X 2014 r.

21 K. Gie rdzi ej ew s ki, op. cit., s. 123. 
krucyfiks i książki. Poniżej widnieje imię dzwonu: „B. VINCENTIUS KADŁUBEK". Po stronie przeciwnej - także w owalu - znajduje się herb Złota Wolność $z$ kapeluszem i sznurem opackim, pod nim napis: „ILLUSTRISSIMUS REVERENDISSIMUS DOMINUS ADALBERTUS ZIEMNICKI ABBAS ANDREOVIENSIS O.C. HANC CAMPANAM COMPARAVIT". Pas odsercowy zdobi niewielki fryz rokokowego ornamentu, a kabłakki korony groteskowe maszkarony ${ }^{22}$. Drugi instrument ma identyczne napisy i dekorację, $z$ tym że $\mathrm{w}$ miejsce plakietki $z$ wizerunkiem bł. W. Kadłubka umieszczono całopostaciowe przedstawienie św. Wojciecha, biskupa i męczennika. Święty odziany jest w szaty biskupie, na głowie ma infułę. Prawa rękę wznosi w geście błogosławieństwa, w lewej zaś trzyma pastorał i wiosło. Pod reliefem widnieje napis: „ST. ADALBERTUS EP MARTYR"23. Warto dodać, że oba te zabytki wyróżniaja się $\mathrm{w}$ zakresie epigrafiki, ponieważ pierwsze duże litery napisów umieszczonych na płaszczu są większych rozmiarów niż pozostałe, także wykonane kapitała humanistyczna. U innych ludwisarzy takie wyróżnienie wiązało się niemal zawsze $z$ komponowaniem chronostychów, natomiast tylko na dzwonach Kocha (a także Jana Gotfryda i Emanuela Wittwercków) ${ }^{24}$ znane jest tego typu podkreślenie rangi wyrazów w napisie.

Warsztat Karola Gotfryda Anthony'ego, odlewnika gdańskiego czynnego w latach $1766-1802^{25}$, reprezentuja dwa spiżowe dzwony z 1781 i 1784 r., wykonane dla kościoła pw. św. Szczepana w Mnichowie (pow. jędrzejowski). Dzieła te sa jak gdyby bliźniacze. Oba

22 Dzwon ten używany jest tylko w czasie wielkich uroczystości oraz pogrzebów zmarłych zakonników konwentu jędrzejowskiego. Por. A.A. D u d e k, Jędrzejów. Archiopactwo cystersów, Warszawa 1991, s. 56.

23 J. Wiśn niewski, Historyczny opis kościołów [...] w Jędrzejowskiem..., s. 60; J. Koł a c z k ow s ki, op. cit., s. 398; A.Z. H e 1 c e 1, O klasztorze jedrzejowskim $i$ bedacym tam nagrobku Pakosława kasztelana krakowskiego, nadbitka $z$ „Rocznika Towarzystwa Naukowego $z$ Uniwersytetem Jagiellońskim złączonego. Oddział sztuki i archeologii”, t. I, z. 2, Kraków 1852, s. 6-7; ADK, Akta kurialne ogólne. Sprawozdania o dzwonach kościelnych zabranych przez władze niemieckie 1941-1947, sygn. OD-11/4, k. 69; materiały inwentaryzacyjne w zbiorach autorki. Karty ewidencyjne obu zabytków, opracowane przez M.P. Przypkowskiego w 1972 r., przechowywane sa w WUKZ w Kielcach.

24 Chodzi tu o dzwon odlany przez J.G. Wittwercka dla kościoła w Krzyżanowicach z 1735 r. (por. E. W róblew s ka, op. cit., s. 71) oraz instrument wykonany przez jego młodszego brata dla cystersów jędrzejowskich (1765 r.).

25 Więcej na temat tego rzemieślnika i jego działalności odlewniczej por. ibidem, s. 77-79. 


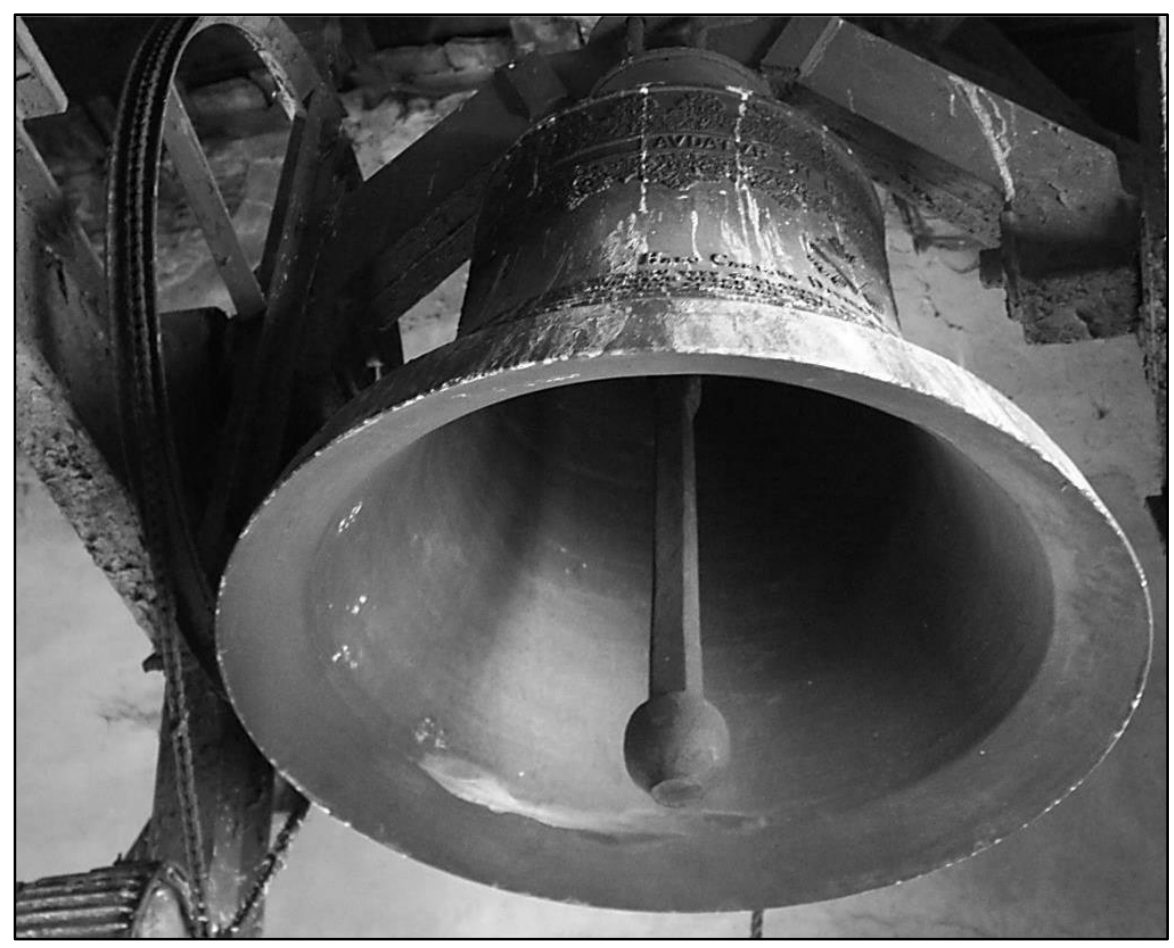

6. Kościół cystersów w Jędrzejowie, dzwon odlany w Gdańsku przez Emanuela Wittwercka, 1765 r.

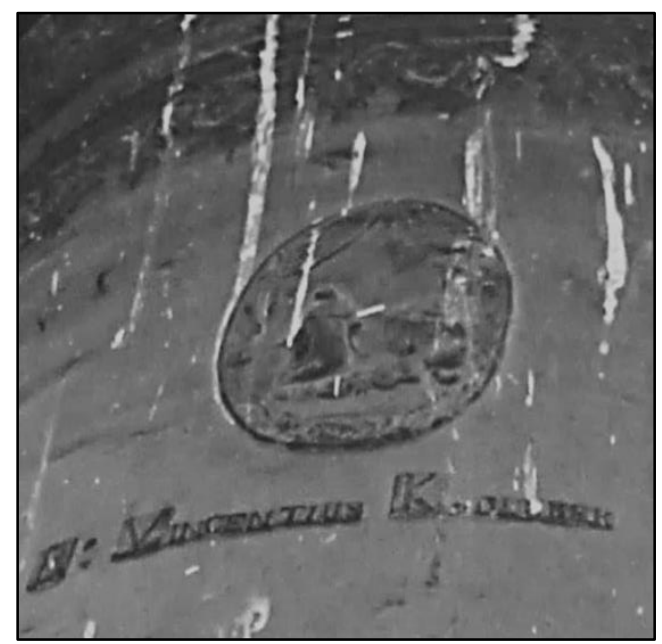

7. Plakietka $\mathrm{z}$ wizerunkiem bł. W. Kadłubka na dzwonie Ernesta Fryderyka Kocha $z$ Jędrzejowa, 1768 r.

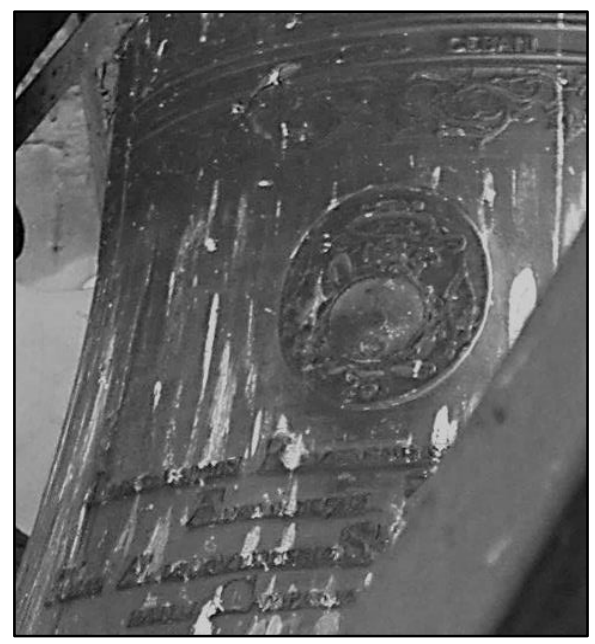

8. Herb Złota Wolność na dzwonie z Jędrzejowa, 1768 r. 


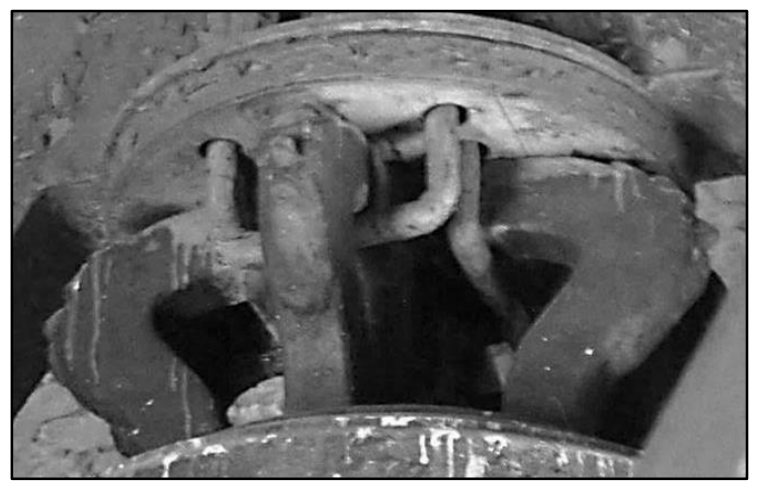

9. Kościół cystersów w Jędrzejowie, dzwon Ernesta Fryderyka Kocha, 1768 r., dekoracja kabłaków korony

mają też znaną $z$ wielu prac sentencję biblijną: „SOLI DEO GLORIA", datę odlewu oraz sygnaturkę ludwisarską. Na starszym $z$ dzwonów imiona mistrza zostały zapisane tylko w formie inicjałów. Poza tym wyróżnia go plakietka $z$ wizerunkiem Matki Boskiej umieszczona na płaszczu. Drugi zabytek dekoruje przedstawienie Oka Opatrzności26.

Jeśli chodzi o ludwisarzy krakowskich działających w wieku XVIII, to należy stwierdzić, że najwięcej realizacji przeznaczonych dla kościołów diecezji kieleckiej wyszło $z$ pracowni Weidnerów ${ }^{27}$. Najstarszy przedstawiciel tej rodziny ludwisarskiej, mosiężnik Jan Zygmunt Weidner (zm. 1766), w krótkim odstępie czasu odlał dla interesującej nas diecezji aż dziewięć dzwonów, większość z nich przetrwała do dziś. W roku 1757 powstały dzwony ze Złotnik (pow. jędrzejowski) ${ }^{28}$ i Rogowa (pow. pińczowski) ${ }^{29}$, w roku następnym

26 J. Wiśniewski, Historyczny opis kościołów [...] w Jędrzejowskiem..., s. 294; E. Wróblew s k a, op. cit., s. 77; CIP, t. I, z. 2, s. 142-143, nr 155, 156. Katalog zabytków (t. III, z. 3, s. 24) wzmiankuje tylko dzwon z 1784 r. Karta ewidencyjna tego obiektu znajduje się w WUOZ w Kielcach. Nadmieńmy w tym miejscu, że Karol Gotfryd Anthony wykonał w 1782 r. jeszcze jeden dzwon dla kościoła mnichowskiego, zarekwirowany przez okupacyjne władze niemieckie w 1943 r. Ważył on $120 \mathrm{~kg}$ i miał na szyi identyczną sentencję, co pozostałe. Praca sygnowana była pełnymi imionami i nazwiskiem twórcy. Por. M. Ka r k o c h a, Dzwony kościelne..., s. 103, 111. Więcej na temat działalności warsztatu ludwisarskiego Anthonych por. E. W r ó b 1 e w s k a, op. cit., s. 73-79.

27 Nazwisko to zapisywane jest także jako Wadner, Waigner, Wainer, Waydner, Waygner.

28 J. Wiśniew ski, Historyczny opis kościołów [...] w Jędrzejowskiem..., s. 406; CIP, t. I, z. 2, s. 166-167, nr 192; Katalog zabytków, t. III, z. 3, s. 44.

29 Katalog zabytków, t. III, z. 9, s. 77; CIP, t. I, z. 4, s. 169, nr 225; Gmina Opatowiec wczoraj $i$ dziś, oprac. M. Komorowska, Opatowic 2014, s. 142, http://opatowiec.pl/wp-content/uploads/2014/10/Gmina-Opatowiec-wczoraj_i_ 
z Gorzkowa (pow. pińczowski - przelany w 1992 r.) 30 i Oleśnicy (pow. staszowski) ${ }^{31}$, w roku 1759 zaś dzwony z miejscowości Cisów (pow. kielecki) ${ }^{32}$, Kossów (pow. włoszczowski) ${ }^{33}$, Kocina (pow. kazimierski - przelany w 2012 r.) ${ }^{34}$, Chotel Czerwony (pow. buski) ${ }^{35}$ oraz Wysocice (pow. miechowski) ${ }^{36}$ - dwa ostatnie bez watpienia zarekwirowane przez Austriaków w czasie I wojny światowej37. Spośród wymienionych najbogatszą - jak się wydaje - dekoracja plastyczna i programem inskrypcji odznacza się instrument $z$ kościoła parafialnego w Złotnikach, znany nam $z$ autopsji (il. 10-12). $\mathrm{Na}$ szyi obiega go ornament wstęgowo-cęgowy. Poniżej znajduje się sentencja zaczerpnięta $z$ Pieśni nad Pieśniami $(2,14)$ : „VOX TUA IN AURIBUS MEIS VOX ENIM TUA DULCIS” („Niechaj głos twój zabrzmi w uszach moich, albowiem głos twój wdzięczny”) i data odlewu („ANNO DO[MINI]1757”), ujęte od dołu fryzem $z$ liści akantu. $\mathrm{Na}$ płaszczu umieszczono następujące inskrypcje: strawestowany

dzis.pdf (dostęp: 25 IX 2015 r.). Karta zabytku w WUOZ w Kielcach, Delegatura w Sandomierzu, oprac. Z. Wojtasiak, 1996 r.

30 Katalog zabytków, t. III, z. 9, s. 24 (tu błędnie datowany na 1759 r.); CIP, t. I, z. 4, s. 60-61, nr 41. W roku 1992 dzwon został przelany w przemyskiej fabryce Felczyńskich z zachowaniem części inskrypcji i dekoracji. Ochrzczono go imieniem Małgorzata, na cześć patronki parafii. Na dzwonie widnieja następujace napisy: „SONET VOX TUA IN AURIBUS MEIS CUSTODI, NOS DOMINE UT PUPILLAM OCULI"; „JAK SŁODKO BRZMI W USZACH MOICH TWÓJ DŹWIEূK. MASZ NA IMIE MAŁGORZATA. MOJE PIERWSZE NARODZINY BYŁY W 1758 R. OD WIELU LAT BYŁEM PĘKNIETY, MARTWY, OŻYŁEM DZIĘKI STARANIOM KS. PRAŁ. ANDRZEJ BIERNACKIEGO ORAZ OFIARNOŚCI PARAFIAN R. P. 1992, GDY PAPIEŻEM BYŁ JAK PAWEŁ II POLAK, A ORD. KIELECKIM KS. BP STANISŁAW SZYMECKI; RENOWACJI DOKONANO W ODLEWNI DZWONÓW I.J. FELCZYŃSKICH W PRZEMYŚLU". Informacja uzyskana od proboszcza parafii, ks. Adama Kędzierskiego, któremu składam w tym miejscu podziękowania.

31 J. Koła c zkow s ki, op. cit., s. 396, 411; W. Sia rkow ski, op. cit., s. 49; CIP, t. I, z. 3, s. 122 , nr 103.

32 Katalog zabytków, t. III, z. 4, s. 23; CIP, t. I, z. 1, s. 77, nr 46. Karta zabytku w WUOZ w Kielcach.

33 J. W i śn i e w s ki, Historyczny opis kościołów [...] w powiecie włoszczowskim..., s. 98; rozmowa $z$ ks. W. Michalskim, proboszczem parafii Kocina, z 20 X $2015 \mathrm{r}$.

34 J. W iś n i e w s ki, Historyczny opis kościołów [...] w Pinczowskiem, Skalbmierskiem $i$ Wiślickiem..., s. 115; rozmowa $z$ proboszczem w Kocinie, ks. W. Michalskim, z 20 X 2015.

35 Ibidem, s. 81.

36 J. W i ś n i e w s k i, Dekanat miechowski..., s. 276.

37 J.J. D re ś c i k, Weidnerowie. Karta $z$ dziejów odlewnictwa krakowskiego, [w:] Ludwisarstwo w Polsce..., s. 61. 
fragment Psalmu 16,8 (17,8): „CUSTODI NOS DOMINE / UT PUPILLAM OCULI” („Strzeż nas, Panie, jako źrenicy oka”); wyjątek z Księgi Rodzaju $(3,15)$ : „IPSA CONTERET / CAPUT TUUM” („Ona zmiażdży ci głowę”); „QUIS UT DEUS” („Któż jak Bóg”); „ECCE AGNUS DEI” („Oto Baranek Boży”, Jan 1,29), powiazane odpowiednio $z$ wyobrażeniem Oka Opatrzności w trójkącie, unoszonego przez dwa anioły; Matki Boskiej $z$ Dzieciatkiem; św. Michała Archanioła zabijającego szatana oraz Chrystusa Zmartwychwstałego. Widnieje na nim także sygnaturka ludwisarza („ME FECIT IOANNE[S] WEIDNER"). Dekorację dzwonu uzupełniają wici roślinne wzbogacone główkami anielskimi, umieszczone na płaszczu poniżej inskrypcji, jak również fryz akantowy na pierścieniu odsercowym ${ }^{38}$.

Opisane inskrypcje i dekoracje można także odnaleźć na pozostałych pracach Jana Zygmunta Weidnera. Cytat z Pieśni nad Pieśniami w całości lub we fragmentach pojawił się na szyjach pięciu innych dzwonów (Rogów, Cisów, Kocina, Gorzków, Wysocice), a strawestowany fragment Psalmu 16 zastosowano na płaszczu jeszcze w trzech przypadkach (Rogów, Oleśnica, Gorzków). Na instrumentach $z$ Oleśnicy i Kossowa - w górnej partii płaszcza umieszczono $z$ kolei wyjątek $z$ Psalmu 129,2: „FIANT AURES TUAE INTENDENTES IN VOCEM DEPRECATIONIS MEAE” („Niech się nakłaniaja uszy twoje na głos modlitwy mojej"). Jeśli idzie o dekorację figuralna, to należy stwierdzić, że znane $z$ dzwonu w Złotnikach przedstawienie Oka Opatrzności unoszonego przez dwa anioły widnieje także na zabytkach $z$ Rogowa i Oleśnicy, plakietka Matki Boskiej $z$ Dzieciatkiem na dzwonach $z$ Cisowa $i$ Wysocic, a relief ukazujący św. Archanioła Michała na paramencie $z$ Kociny. Wizerunek Pana Jezusa na krzyżu wystąpił na pięciu pracach ${ }^{39}$, ale na dzwonie $z$ Oleśnicy zestawiono go $z$ napisem: „MORS TUA VITA MEA” („Twoja śmierć jest moim życiem”). W pojedynczych przypadkach użyto plakietki $z$ wizerunkiem św. Jana (Wysocice), medalion $z$ popiersiem „świętego biskupa” (Kossów) oraz herb Szreniawa (Rogów). Jak więc widać, wyroby omawianego ludwisarza charakteryzują się stosunkowo bogatą dekoracją ornamentalno-figuralną, sa jednak mało zróżnicowane.

38 J. Wiśniew ski, Historyczny opis kościołów [...] w Jędrzejowskiem..., s. 406; CIP, t. I, z. 2, s. 166-167, nr 192; Katalog zabytków, t. III, z. 3, s. 44; C. Ha d a m i k, D. Kal in a, E. Traczyń s ki, op. cit., s. 217; WUOZ w Kielcach, karta ewidencyjna zabytku ruchomego, oprac. S. Fiedorczuk, 1986 r.; J.J. D r e s c i k, op. cit., s. 65.

$39 \mathrm{Na}$ dzwonach z Cisowa, Kociny, Kossowa, Oleśnicy i Wysocic. 


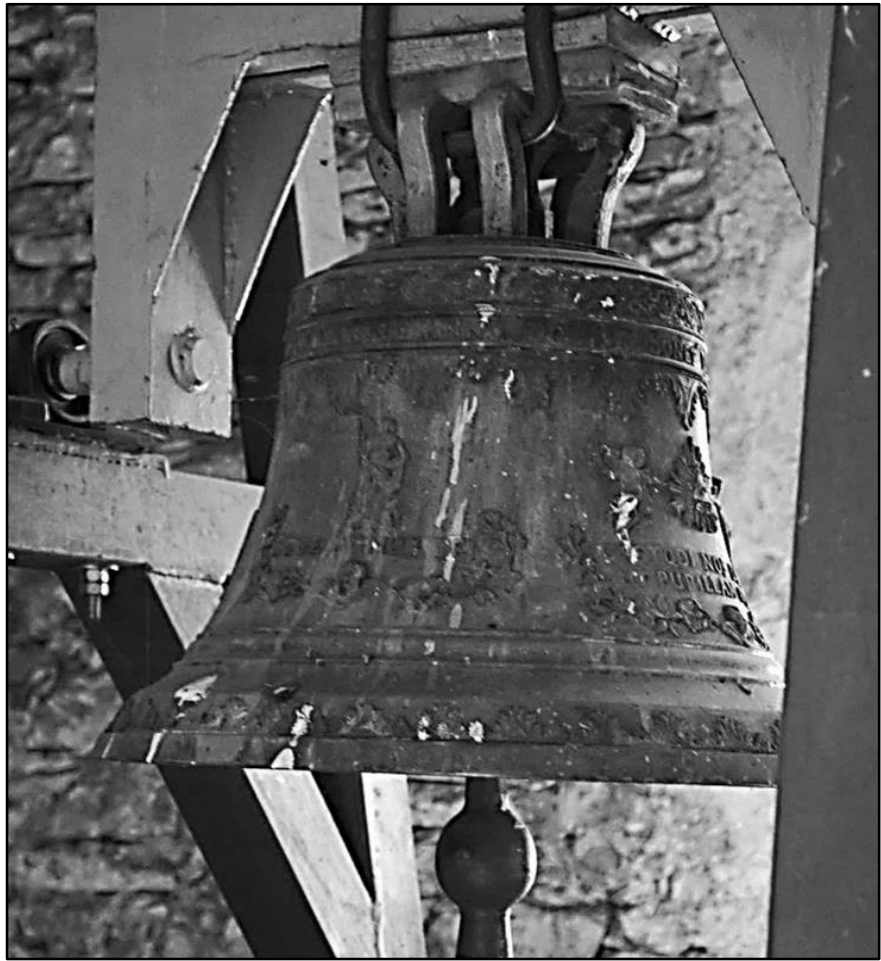

10. Kościół pw. Wszystkich Świętych w Złotnikach, dzwon Jana Zygmunta Weidnera, 1757 r.

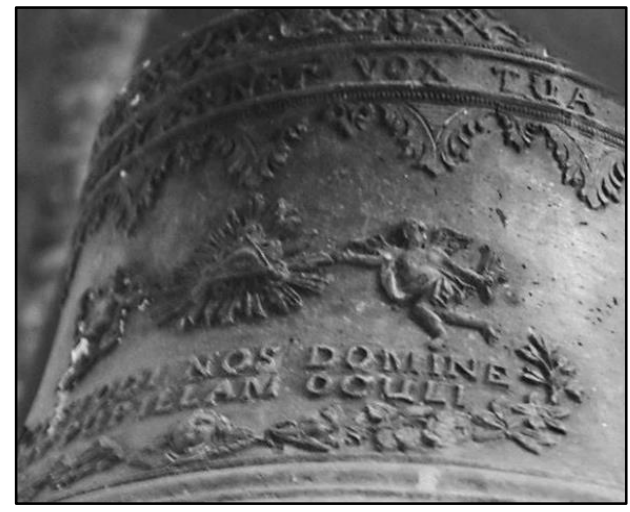

11. Plakietka $z$ wyobrażeniem Oka Opatrzności podtrzymywanym przez dwa anioły na dzwonie J.Z. Weidnera w Złotnikach, 1757 r.

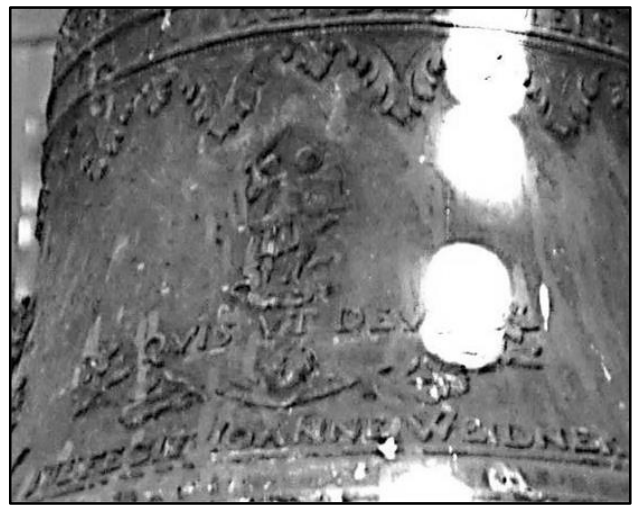

12. Dzwon w Złotnikach z 1757 r., fragment dekoracji płaszcza $z$ plakietka św. Michała Archanioła i sygnaturka ludwisarza 


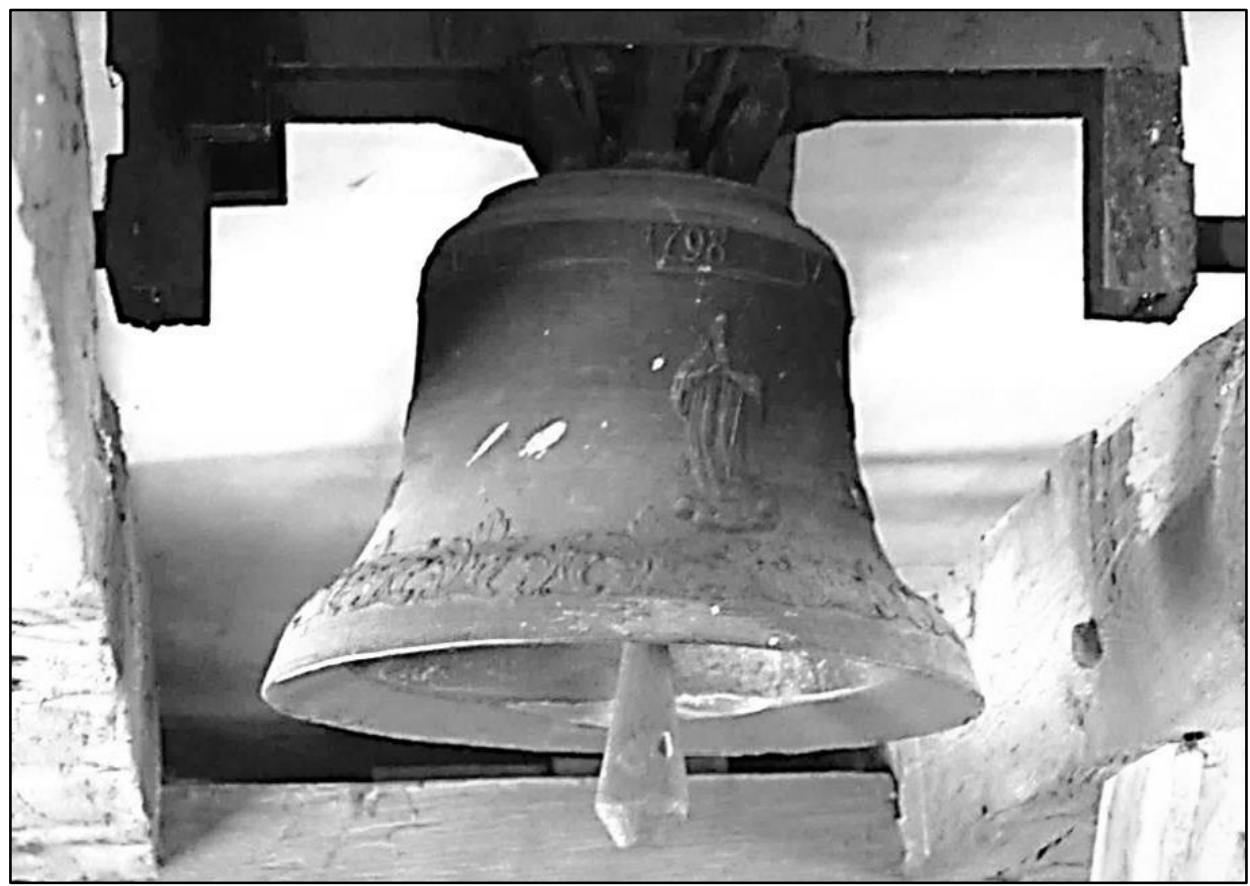

13. Dzwon Piotra Weidnera w wolno stojącej dzwonnicy przy kościele parafialnym w Rembieszycach, 1798 r.

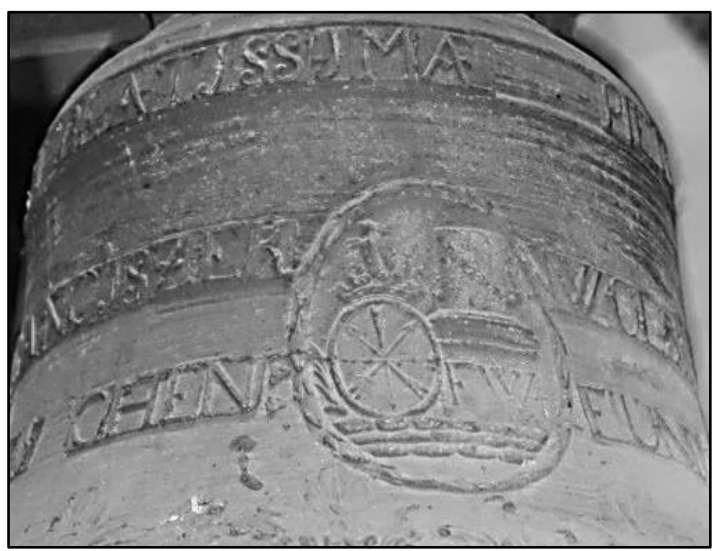

14. Plakietka $z$ herbem Jelita na dzwonie w Rembieszycach, 1798 r.

Starszy syn i następca Jana Zygmunta - Maciej Weidner (zm. 1782) - wykonał w 1778 r. dzwon dla kościoła parafialnego w Książnicach Wielkich (pow. proszowicki), przetopiony w Węgrowie na poczatku ubiegłego stulecia staraniem miejscowego proboszcza - 
Franciszka Staszkiewicza. Widnieją na nim imię dzwonu („Nomen Thomas”), sygnaturka mistrza („Me fecit Mathias Waindner Cracovia 1778 ”) oraz sentencja biblijna: „Si vocem eius audieritis nolite obdurare corda vestra” („Jeśli głos jego usłyszycie, nie zatwardzajcie serc waszych", Hbr 3,15; także 4,7). Napis dodany po przelaniu głosi: „Transfusa A. D. 1902 cura Fr. Staszkiewicz parochii Książnicen[sis]"40. Ponadto wiadomo, że Maciej był twórca dzwonu w Koniuszy z 1781 r., przelanego w przemyskiej fabryce Felczyńskich w 1990 r. ${ }^{41}$, a także nieistniejącego dziś instrumentu w Nowym Korczynie z 1778 r., najpewniej zarekwirowanego w czasie I wojny światowej42.

Ostatni przedstawiciel tego rodu - Piotr Maciej Weidner (17631808), młodszy, przyrodni brat Macieja $z$ trzeciego małżeństwa ojca z Katarzyną Plucieńską4 - jest autorem dwóch zachowanych do dziś dzwonów, przeznaczonych dla świątyń parafialnych w Rembieszycach i Oksie (obie te miejscowości w powiecie jędrzejowskim), datowanych na $1798 \mathrm{r}$. Pierwszy $z$ nich, $z$ napisem na szyi: „IN HONOREM BEATISSIMAE PIETR WAINER 1789”, powstał $z$ inicjatywy Franciszka Sariusza Wolskiego (zm. 1836) ${ }^{44}$, podwojewodziego chęcińskiego, dziedzica Rembieszyc i fundatora tamtejszego kościoła, o czym informuja pamiątkowa inskrypcja umieszczona na płaszczu: „WI[ELMOŻNY] P[AN] FRANCISZEK WOLSKI / PODWOIEWODZY CHEN[CINSKI] FUNDATOR" oraz herb Jelita ${ }^{45}$. Na

40 J. W iśn niew s ki, Historyczny opis kościołów [...] w Pinczowskiem, Skalbmierskiem $i$ Wiślickiem..., s. 181; Katalog zabytków, t. III, z. 9, s. 43; J. K oł a c zk ow s ki, op. cit., s. 406.

41 Pierwotnie na szyi dzwonu znajdowały się cytat z Pieśni nad Pieśniami: „Vox tua in auribus meis”, sygnaturka autorska i data odlewu („Me fecit Mathias Wardner in Cracovia 1781"), a na płaszczu plakietki $z$ wyobrażeniami Trójcy Świętej i św. Floriana (J. W iś n i e w s ki, Dekanat miechowski..., s. 68). Po przelaniu na instrumencie umieszczono $z$ jednej strony przedstawienie św. św. Piotra i Pawła, z napisem: „Święci Piotrze i Pawle módlcie się za nami”, z drugiej zaś inskrypcję: „W Jubileuszowym Roku Odkupienia i w stulecie diecezji kieleckiej. Parafia Koniusza 1990". Informacja uzyskana od proboszcza parafii, ks. Władysława Banika w dniu 23 X 2015, któremu składam w tym miejscu wyrazy wdzięczności.

42 J. Koła c z k ow s ki, op. cit., s. 396, 406; W. S i a r kow s ki, op. cit., s. 49.

43 J.J. D r és cik, op. cit., s. 61.

44 Więcej na temat tej postaci por. S. Borkiewicz, Z. Linowski, Monografia historyczna i gospodarcza ziemi jędrzejowskiej, Kielce 1937, s. 171-172; M. K a r k o c h a, Parafia Rembieszyce 1438-2012. Studium z dziejów społeczności lokalnej, Łódź 2013, s. 23 i n.

45 Cyt. za: CIP, t. I, z. 2, s. 154, nr 172. Por. też J. W i ś n i e w s k i, Historyczny opis kościołów [...] w Jędrzejowskiem..., s. 337; Katalog zabytków, t III, z. 3, 
dzwonie widnieje także dużych rozmiarów plakietka $z$ wyobrażeniem Trójcy Świętej (?) w chmurach. Wieniec zdobi rokokowy fryz złożony $z$ większych i mniejszych liści akantu, występujących naprzemiennie (il. 13-14). Drugi instrument - wykonany dla Oksy powstał na zlecenie miejscowego plebana Mateusza Janczarskiego46. Ma on na szyi majuskułowa, wotywno-poświadczeniowa inskrypcję: „AD M[AIOREM] D[EI] G[LORIAM] ET B[EATAE] V[IRGINIS] / J[EGOMOSC] X[IĄDZ] MATEUSZ JANCZARSKI PLEBAN FUNDATOR 1789", ujęta od dołu szerokim fryzem $z$ liści akantu (drugi, analogiczny, tylko węższy, widnieje na pasie odsercowym). Na płaszczu znajduja się sygnaturka mistrza („PIETR WAINER”) oraz plakietki $z$ przedstawieniami Trójcy Świętej i św. Michała47. Wiadomo także o istniejących niegdyś dzwonach tego ludwisarza w Piekoszowie (pow. kielecki) z 1795 r., w Kozłowie (pow. miechowski) i Żębocinie (pow. proszowicki) - dwa ostatnie z 1803 r., zarekwirowanych w czasie I wojny światowej48, jak również o kilku innych odlanych dla kościołów małopolskich ${ }^{49}$.

Pochodzący $z$ Węgier ludwisarz Ignacy Hutlauer (Huflauer, Huflaner), współpracownik Macieja Weidnera, żonaty $z$ wdowa po tym mistrzu, przelał w 1789 r. „Na cześć i chwałę Boga” dzwon z kościoła parafialnego w Kijach w powiecie pińczowskim (stary dzwon wykonany był w 1569 r.) ${ }^{50}$, a na początku XIX w. instrument z po-

s. 33; J. Koła c zkow s ki, op. cit., s. 396, 414; W. Si a r k ow s ki, op. cit., s. 49; M. Ka r k o ch a, Parafia Rembieszyce..., s. 194-195; C. H a d a m i k, D. Ka lin a, E. Traczyńs ki, op. cit., s. 210.

46 Mateusz Janczarski był proboszczem w Oksie od 1778, co najmniej do 1802 r. Por. J. Wiśniewski, Historyczny opis kościołów [...] w Jędrzejowskiem..., s. 322 .

47 Nie jest to św. Florian, jak sugeruje J.J. D re ś c i k (op. cit., s. 69). Por. też J. W i śn niew ski, Historyczny opis kościołów [...] $w$ Jędrzejowskiem..., s. 320; Katalog zabytków, t III, z. 3, s. 31; CIP, t. I, z. 2, s. 151, nr 166. Ilustrację dzwonu zamieścił J.J. Dreścik w cytowanym już artykule (s. 68).

48 J. W iśniews ki, Dekanat miechowski..., s. 72, 290; id e m, Dekanat konecki..., s. 193.

49 Wylicz je J.J. D r e ś c ik, op. cit., s. 69 (literatura przedmiotu na s. 74).

50 Na dzwonie napis: „CAMPANAM QVAM GENEROSVS CHRISTOPHORUS PASIENSKI BVRGRABIVS CRACOWIENSYS WICEKYE HERES FIERIS / CURAVIT ANNO 1569 TEMIP|ORE ET IN KURIA FRACTAM IGNACIUS CORWIN BIENKOWSKY SCHOLASTICVS CATEDRALIS / CRACOWIENSIS PREPOSITUS KIENSIS RURSUS CONCTARI FECIT A[NNO] D[OMINI] 1789 AD LAUDEM ET GLORIAM DEI NEC NON VENERATI/ONEM BEATORUM APOSTOLORUM PETRI ET PAULI PATRONORUM ECCLESIE KIENSIS CRACOVIE ME FECIT IGNACI HUTLAU". Cyt. za: CIP, t. I, z. 4, s. 72, nr 60. Por. też Katalog zabytków, t. III, z. 9, s. 32; J. W i - 
bliskiego Bobina (ten sam powiat). Pierwszy $z$ wymienionych został przetopiony $z$ polecenia ks. Ignacego Korwina Bieńkowskiego (zm. 1793), scholastyka i prepozyta krakowskiego, dobrodzieja miejscowej swiatyni51. Fundatorem drugiego był proboszcz parafii Bobin, ks. Józef Jagielski52. W pracowni Hutlauera powstał też spiżowy dzwon wykonany dla bożogrobców miechowskich w 1790 r., przelany jednak w Warszawie w roku 188753.

Niewattpliwie czołowy odlewnik działający w stolicy Małopolski w drugiej połowie XVIII w. Baltazar (Balcer) Ruszkowski (vel Roszkiewicz, Rośkiewicz) pozostawił na terenie diecezji kieleckiej spora grupę paramentów, $z$ których niektóre sygnowane sa: „Polonus [me] fecit”. Charakteryzuja się one bogata dekoracja ornamentalna i figuralna oraz rozbudowanym programem inskrypcyjnym. Ulany w roku 1759 „duży” dzwon dla świątyni parafialnej w Koniuszy, ma na szyi cytat $z$ Księgi Daniela: „BENEDICTE OMNIS IMBER ET ROS DOMINO, BENEDICTE OMNES SPIRITUS DOMINO" (Dn 3,61,73 - „Błogosławcie Pana, deszcze i rosy, błogosławcie Pana, wszystkie duchy") i datę odlewu. Poniżej, na płaszczu, widnieją sentencje zaczerpnięte $z$ Psalmów: „IN OMNEM TERRAM EXIVIT SONUS EORUM” (Ps 18,5 [19,5] - „Ich głos się rozchodzi na cała ziemię"); „ET LAUDABUNTUR OMNES RECTI CORDE” (Ps 63,11 [64,11] - „A wszyscy prawego serca się chlubią); „A SOLIS ORTU USQUE AD OCCASUM, LAUDABILE NOMEN DOMINI" (Ps 112,3 $[113,3]$ - „Od wschodu słońca aż do jego zachodu, Niech imię Pań-

śniewski, Historyczny opis kościołów [...] w Pińczowskiem, Skalbmierskiem $i$ Wiślickiem..., s. 108. Instrument ocalał od rekwizycji w czasie II wojny światowej, ponieważ mieszkańcy parafii zakopali go w ziemi, http://www.diecezja.kielce.pl/ parafie/kije-sw-piotra-i-pawla-app (dostęp: 15 IX 2015 r.).

51 Więcej na temat tej postaci por. J. W i ś n i e w s ki, Historyczny opis kościołów [...] w Pinczowskiem, Skalbmierskiem $i$ Wiślickiem..., s. 110; L. Łę t ow s ki, Katalog biskupów, prałatów i kanoników krakowskich, t. I, Kraków 1852, s. 30-31.

52 Data powstania tego zabytku jest niepewna. J. Wiśniewski odczytał na nim rok 1803. Podobnie datuja go wydawcy Katalogu zabytków. Według miejscowego proboszcza, ks. Czesława Parkity, na dzwonie widnieje data 1805. Warto zaznaczyć, że fundator tego dzieła, ks. J. Jagielski, pełnił obowiazki plebana parafii Bobin w latach 1806-1810 (tak przynajmniej podaje J. Wiśniewski). Por. J. W i śniewski, Historyczny opis kościołów [...] w Pinczowskiem, Skalbmierskiem $i$ Wiślickiem..., s. 25, 26; Katalog zabytków, t III, z. 9, s. 7; rozmowa z ks. C. Parkita $z$ dnia $30 \times 2014$ r.

53 Umieszczona na dzwonie inskrypcja głosi: „Thomas Nowiński Praepositus Miechoviensis divis Thomae Apostolo et Augustino dicat. Przelany w Warszawie w 1887 r. za m. proboszcza ks. Kwiatkowskiego". Cyt. za: J. W iś n i e w s k i, Dekanat miechowski..., s. 131. Por. też Katalog zabytków, t. I, z. 8, s. 24. 
skie będzie pochwalone”); „BENEFAC DOMINE BONIS ET RECTIS CORDE” (Ps 124,4 [125,4] - „Panie, dobrze czyń dobrym i ludziom prawego serca"), jak również fragment popularnej modlitwy Anioł Pański: „ET VERBUM CARO FACTUM EST” („A Słowo stało się ciałem”). Plakietki umieszczone na płaszczu przedstawiaja Pana Jezusa na krzyżu, Immaculate, patronów kościoła - św. św. Apostołów Piotra i Pawła, a także herb Trzy Trąby, odnoszacy się zapewne do fundatora tego dzieła. Na kabłakach znajduje się słabo widoczna sygnaturka mistrza („Polonus fecit”) ${ }^{54}$.

$Z$ roku 1767 pochodzi zespół trzech dzwonów wykonanych dla kościoła pw. św. Mikołaja w Skale (pow. krakowski), sygnowanych: „POLONUS FECIT. B. R.”. Na pierwszym $z$ nich umieszczono wyjatek $z$ Księgi Daniela, ten sam, co na dzwonie w Koniuszy, jak również słowa $z$ Listu do Hebrajczyków („SI VOCEM EIUS AUDIERITIS, NOLITE OBDURARE CORDA VESTRA"). Drugi dzwon opatrzony został sentencją: „LAUDATE DOMINUM IN SANCTIS EIUS, LAUDATE EUM IN CYMBALIS BENESONANTIBUS, LAUDATE EUM IN CYMBALIS JUBILATIONIS” (Ps 150,1,5 - „Chwalcie Pana w Jego świętobliwości, chwalcie Go na cymbałach głośnych, chwalcie Go na cymbałach dźwięcznych"), a ostatni cytatami z Psalmów 5, 18 i 3355. Trudno cokolwiek powiedzieć o dekoracji tych zabytków, gdyż nie sa nam znane $z$ autopsji, w literaturze przedmiotu zaś odnotowano jedynie treść inskrypcji.

Dzwon z Kazimierzy Wielkiej (pow. kazimierski), o wadze 420 kg, ma na szyi podwójny fryz ornamentalny: górny skomponowany $z$ fleur-de-lis, dolny $\mathrm{w}$ formie lambrekinu $\mathrm{z}$ chwostami. Pomiędzy fryzami widnieje sentencja: „SI VOCEM EIUS AUDIERITIS. NOLITE OBDURARE CORDA VESTRA" (Hbr 3,15; 4,7). Płaszcz zdobi od frontu przedstawienie Chrystusa na krzyżu, poniżej którego

54 J. Wiśn iewski, Dekanat miechowski..., s. 68; J. Kołaczkowski, op. cit., s. 406.

55 Ps 5,8: „INTROIBO IN DOMUM TUAM, ADORABO AD TEMPLUM SANCTUM TUUM IN TIMORE TUO” („Wejdę do Twojego domu, upadnę przed świętym przybytkiem Twoim przejęty Twoją bojaźnią); Ps 18,5 $(19,5)$ : „OMNEM TERRAM EXIVIT SONUS ET IN FINES ORBIS TERRAE VERBA EORUM” („Ich głos się rozchodzi na cała ziemię i aż po krańce świata ich mowy”); Ps 33,12 (34,12): „VENITE FILII AUDITE ME TIMOREM DOMINI DOCEBO VOS” („Pójdźcie, synowie, słuchajcie mnie, nauczę was bojaźni Pańskiej”). Cyt. za: J. Wi ś n ie w s ki, Historyczny opis kościołów, miast, zabytków i pamiatek $w$ Olkuskiem..., s. 380. Por. też Katalog zabytków, t. I, z. 12, s. 33 (tu wzmiankowane tylko dwa dzwony); B. C e d n a, D. C e d n a, Kościoły, kaplice $i$ dzwonnice drewniane. Województwo małopolskie. Część północna. Przewodnik, Pruszków 2011, s. 99. 
umieszczono napis: „IESUS NASARENUS REX / IUDEORUM MISERERE NO/BIS" i rok odlewu (1776). $Z$ prawej strony znajduje się plakietka $z$ wizerunkiem św. Magdaleny, $z$ łacińska sentencja „ECCE DEUS SALVAT[O]R MU[NDI]S”, z lewej zaś przedstawienie św. Michała Archanioła $z$ ułożonym fantazyjnie napisem: „QUIS SICUT DOMINUS DEUS NOSTER, QUI IN ALTIS HABITAT" (Ps 12,5 [113,5] - „Któż jak nasz Pan Bóg, co siedzibę ma w górze”). Ścianę tylna dzwonu zdobi wyobrażenie Immaculaty w promienistej aureoli, z majuskułowym napisem: „Non nobis Domine non nobis. Sed nomini tua da Gloriam” (Ps 115,1 - „Nie nam, Panie, nie nam, lecz Imieniu Twemu niech będzie chwała"). Zabytek opatrzony jest sygnaturką: „Baltasar Polonus fecit” 56.

Inna praca omawianego tu rzemieślnika jest instrument ze Stradowia w powiecie kazimierskim, sprawiony w 1780 r. staraniem miejscowego plebana - ks. Szymona Gorczyńskiego. Informuje o tym stosowna inskrypcja umieszczona na szyi. Na dzwonie widnieja także data odlewu, sygnaturka poświadczeniowa („POLONUS ME FECIT”) oraz popularna sentencja biblijna: „SI VOCEM EIUS AUDIERITIS NOLITE OBDURARE CORDA", zaczerpnięta $z$ Listu do Hebrajczyków ${ }^{57}$.

$Z$ pracowni Ruszkowskiego wyszedł też dzwon $z$ kościoła pw. św. Marcina w Wodzisławiu (pow. jędrzejowski), ulany w roku 1787. Powstał on $\mathrm{z}$ inicjatywy hr. Macieja Lanckorońskiego (zm. 1789), wojewody bracławskiego, kawalera Orderu Orła Białego, co poświadcza wotywna inskrypcja w języku polskim, uwidoczniona na płaszczu58. Szyję paramentu zdobi łacińska sentencja: „A SOLIS ORTU USQUE AD OCCASUM LA[U]DABILE NOMEN DOMINI" (Ps $112[113], 3)^{59}$.

56 Katalog zabytków, t. III, z. 9, s. 28; CIP, t. I, z. 4, s. 65, nr 50; karta ewidencyjna (bez opisu) w WUOZ w Kielcach. Dodajmy tylko, że wierna ikonograficznie replikę omawianego dzwonu można podziwiać w Parku Etnograficznym $\mathrm{w}$ Tokarni, w oryginalnej XIX-wiecznej dzwonnicy przeniesionej $z$ Kazimierzy Wielkiej. Instrument odlano w 2008 r. w ludwisarni Felczyńskich w Taciszowie dzięki funduszom Ministerstwa Kultury i Dziedzictwa Narodowego. Por. http://swietokrzyskie.org.pl/warto-zobaczyc/zabytki/1315-tokarnia-drewnianadzwonnica-z-kazimierzy-wielkiej-w-parku-etnograficznym (dostęp: 10 IX 2015 r.).

57 Katalog zabytków, t. III, z. 9, s. 94; CIP, t. I, z. 4, s. 197-198, nr 270; J. Wi śnie wski, Historyczny opis kościołów [...] w Pinczowskiem, Skalbmierskiem $i$ Wiślickiem..., s. 420.

58 W.A. Se rczyk, Lanckoroński Maciej, [w:] PSB, t. XVI, Wrocław 1971, s. 445 .

59 CIP, t. I, z. 2, s. 163-164, nr 187. 
Przelanym dziełem Baltazara Ruszkowskiego jest instrument z 1789 r., umieszczony w dzwonnicy kościoła katedralnego w Kielcach. Dzwon ma na szyi majuskułową inskrypcję: „TOT RESONARE DEO LAUDES QUOT VERBERA SUFFERS” („Obyś tyle przyniósł chwały Bogu, ile razy doznajesz uderzeń"), ujęta od góry bogatym ornamentem regencyjnym, a od dołu lambrekinem $z$ frędzlami. Przed napisem, jako poczatnik, widnieje plakietka $z$ wizerunkiem Matki Boskiej. Poniżej, w górnej partii płaszcza, umieszczono cytat z Księgi Psalmów: „DEUS MAGNUS DOMINUS ET REX MAGNUS SUPER OMNES DEOS SI VOCEM EJUS AUDIERITIS NOLITE OBDURARE CORDA VESTRA" (Ps 94,3,8). Na ścianie bocznej znajduje się inskrypcja mówiąca o tym, że dzwon został sprawiony „Na większą chwałę Boga” kosztem kapituły krakowskiej, a po przeciwnej stronie fragment $z$ Księgi Psalmów: „LAUDATE DOMINUM IN SANCTIS / EIUS / LAUDATE EUM IN CYMBALIS / BENESONANTIBUS LAUDATE EUM / IN CYMBALIS JUBILATIONIS" (PS $150,1,5)^{60}$.

Osobnego omówienia wymaga instrument $z$ kościoła pw. św. Jana Chrzciciela w Skalbmierzu, noszacy datę 1784, przelany $\mathrm{w}$ latach sześćdziesiątych ubiegłego stulecia $z$ zachowaniem oryginalnej formy i zdobień. Cechuje go bogaty zespół inskrypcji i dekoracji, najpełniejszy - jak się wydaje - w dorobku interesującego nas ludwisarza. Dzwon ten, o średnicy $117 \mathrm{~cm}$ i zbliżonej wysokości $(115 \mathrm{~cm})$, nosi imię Jan Chrzciciel. Na szyi zdobi go szeroki pas horyzontalnie położonego ornamentu kandelabrowego, skomponowany $z$ bujnych pęków giętkich liści akantu. Poniżej biegnie majuskułowa sentencja w języku łacińskim: „TOT RESONARE DEO LAUDES QUOD VERBERA SUFFERS” (Ps 94,3), ujęta od dołu arabeskami oraz rzędem 22 niewielkich plakietek $z$ motywem uskrzydlonych główek anielskich. Wszystkie cztery ściany dzwonu dekoruja płaskorzeźby i inskrypcje. $Z$ przodu widnieje wyobrażenie Pana Jezusa na krzyżu, po bokach którego jest napis: „BENE FAC DOMINE BONIS ET / RECTIS CORDE” („Panie, dobrze czyń dobrym i ludziom prawego serca", Ps 124,4 [125,4]). Nad krucyfiksem uwidoczniono datę odlewu („A. D. 1784”). Po przeciwnej stronie znajduje się przedstawienie św. św. Apostołów Piotra i Pawła, opa-

60 Katalog zabytków, t. III, z. 3, s. 31; CIP, t. I, z. 1, s. 122, nr 100; J. Z d a now s ki, Kościół katedralny Najświętszej Marii Panny w Kielcach, Kielce 1930, s. 5; J. Koła c z k ow ski, op. cit., s. 405; WUOZ w Kielcach, karta ewidencyjna zabytku ruchomego, oprac. D. Paprocka, 1966 r. 
trzone sentencją biblijną: „IN OMNEM TERRAM EXIVIT SONUS EORUM / ET IN FINESORBIS TERRAEVERBA EORUM” („Ich głos się rozchodzi na cała ziemię i aż po krańce świata ich mowy", Ps 18,5 [19,5]). Od strony wschodniej umieszczono scenę Chrztu Chrystusa w Jordanie, nad która napis: „EGRESSUS ES IN SALUTEM POPULI / TUI IN SALUTEM CUM CHRISTO TUO” („Wyszedłeś w celu ocalenia swego ludu, w celu wybawienia Twego pomazańca”, Hab. 3,13). Poniżej biegnie półkolem inskrypcja: „BONITATEM FECISTI CUM SERVO TUO DOMINE” („Wyświadczyłeś, Panie, dobro swojemu słudze", Ps 118,65 [119,65]). Ścianę zachodnia wypełniają w całości cytaty zaczerpnięte $z$ Księgi Psalmów: „NON NOBIS DOMINE NON NOBIS / SED NOMINI TUO DA GLORIAM / SIT NOMEN DOMINI BENEDICTUM / EX HOC ET USQUE AD OCCASUM / A SOLI ORTU USQUE IN SAECULUM / LAUDABITE NOMEN DOMINI" (Ps 112,2-3 [113,2-3]; 115,1). Na płaszczu znajduje się również inskrypcja dodana po przelaniu, umieszczona $\mathrm{w}$ pięciu wierszach, rozdzielona scena Chrztu. Głosi ona: $z$ jednej strony - „KOSZTEM PARAFII / PRZELAN DZWON TEN / POD IMIENIEM JAN / J. DOBRZYŃSKI Z WEGROWA / ROKU 1965", $z$ drugiej strony - „Z ZACHOWANIEM PIERWOTNEJ / ORNAMENTYKI I ORYGINALNYCH / NAPISÓW ZA PASTERSKICH / RZĄDÓW / KS. JAKUBA KULIŃSKIEGO”. Wieniec zdobi w połowie wysokości wąski fryz ze stylizowanych lilii heraldycznych ${ }^{61}$.

Warto nadmienić, że przed przetopieniem instrumentu w górnej partii płaszcza znajdowała się inskrypcja wyjęta z Psalmu 148: „LAUDATE DOMINUM DE COELIS, LAUDATE EUM IN EXCELSIS, LAUDATE CUM OMNES ANGELI. IGNIS, GRANDO, NIX, GLACIES, SPIRITUS PROCELLARUM QUAE FACIUNT VERBUM EIUS”, co wskazuje bez wattpienia na apotropaiczna funkcję tego zabytku. Widniała na nim również sygnaturka autorska: „Non Germanus sed Polonus. Me fecit Batasor"62.

Najpewniej także Ruszkowskiemu należy przypisać autorstwo „średniego" dzwonu $z$ kościoła parafialnego w Skalbmierzu, pochodzacego z 1756 r., przelanego po II wojnie światowej. Przema-

61 J. Wiśniew ski, Historyczny opis kościołów [...] w Jędrzejowskiem..., s. 392-393; W. Siarkowski, op. cit., s. 45-46; J. Kołaczkow ski, op. cit., s. 399, 416; WUOZ w Kielcach, karta ewidencyjna zabytku ruchomego, oprac. K. Myśliński, 2003 r.

62 Cyt. za: W. Siarkow ski, op. cit., s. 49. Por. J. Wiśn niew ski, Historyczny opis kościołów [...] $w$ Jędrzejowskiem..., s. 392; K. Gie r d zi ej e w s ki, op. cit., s. 130 . 
wia za tym zarówno forma zabytku, jak i zastosowany program inskrypcyjny i dekoracja ornamentalno-figuralna. Parament ten, o wymiarach 100 x 100, obiegana na szyi łacińska inskrypcja: „HODIE SI VOCEM EIUS AUDIERITIS NOLITE OBDURARE CORDA VESTRA" (Hbr 3,15; 4,7; także Ps 94,8), umieszczona między dwoma wysokimi fryzami ornamentalnymi, skomponowanymi $z$ arkadek i ułożonych naprzemiennie lilii oraz rozet. Analogiczny fryz, tylko węższy, widnieje na pasie odsercowym. Płaszcz zdobią na osiach plakietki $z$ przedstawieniami figuralnymi i symbolicznymi, ujęte napisami (kapitała humanistyczna). $Z$ przodu, powyżej Chrystusa Zmartwychwstałego, znajduje się sentencja biblijna - wyjątek $z$ Pieśni nad Pieśniami $(2,14)$ : „SONET VOX TUA IN AURIBUS, VOX ENIM TUA DULCIS”. Po przeciwnej stronie umieszczono wyobrażenie Trójcy Świętej, pod którym znajduje się inskrypcja wotywna: „SUMPTA / VENERABILIS CAPITULI MAJORSI / ECCLESIAE COLEGIATAE / SCALBIMIRIENSIS". Na ścianach bocznych widnieją $z$ jednej strony krzyż i inicjały imienia Jezus, umieszczone w aureoli promienistej, powyżej uskrzydlone główki anielskie, a poniżej napis: „JESUS NAZARENUS / REX JUDEORUM” (J 19,19); $z$ drugiej zaś Matka Boska $z$ Dzieciątkiem na półksiężycu, $z$ napisem: „ET VERBUM / CARO FACTUM EST / ET HABITAVIT IN NOBIS". Obok Marii - w pewnym oddaleniu - unosi się anioł trzymajacy banderolę ze słowami: "OLEUM EFFUSUM O MARIA NOMEN TUUM” („Jako olej wylany, o Maryjo, imię Twoje”, Pnp 1,2). Pomiędzy figura Chrystusa Zmartwychwstałego a aureola $z$ krzyżem widnieje dodana już współcześnie inskrypcja: „PRZELANO W ODLEWNI / DZWONÓW / BOL. DROŻDŻ FR. KUBICA / W DĄBROWIE GÓRNICZEJ / R.P. 1969"63.

W neorenesansowym kościele pw. Bożego Ciała w Słomnikach (pow. krakowski) zachowały się trzy dzwony Józefa Rosemberskiego: jeden $z$ początku XVIII w., dwa $z 1737$ r., ulane pierwotnie dla nieistniejącej świątyni drewnianej w tej miejscowości (il. 15-18). Szyję największego instrumentu zdobi podwójny fryz ornamentalny: górny, węższy, skomponowany $z$ wici roślinnej, dolny w formie płaskich, trójkątnie zakończonych kwiatów. Pomiędzy fryzami, w dwóch rzędach oddzielonych wałkami, biegnie majuskułowa in-

63 Katalog zabytków, t. III, z. 9, s. 87; J. Koła c z k ow s k i, op. cit., s. 416; W. S i a r k ow s k i, op. cit., s. 46-47; WUOZ w Kielcach, karta ewidencyjna zabytku ruchomego, oprac. K. Myśliński, 2003 r. Opis paramentu przed przelaniem por. J. W i ś n i e w s k i, Historyczny opis kościołów [...] w Jędrzejowskiem..., s. 393. 
skrypcja: „VOX MEA, VOX VITAE, VOCO VOS, AD SACRA VENITE” („Głos mój, głos życia, woła was, do świętości przybywajcie”), dołem zaś: „GLORIA TIBI TRINITAS EQUALIS UNA DEITAS” („Chwała Ci, równa w godności, Trójco, jedyny Boże”). Płaszcz dekoruje plakietka Matki Boskiej Niepokalanie Poczętej w podłużnym obramieniu. Ponad nią widnieje korona, a poniżej monogram imienia Maria. Na pierścieniu odsercowym, u wylotu dolnej krawędzi, umieszczono napis: „POST FLAGRANTES TURBITAS FLAMAS 22 MENSE APRILI D.O.M. HOC OPUS OPE DIVINA ET CURATIONER IACOBI VIDERA C. SŁOME. ET FADUCI. PRZE. VICEADU. F. MAT. PP STAN. LANS. CON. CAP. BUGRESIS. TOTIUS COMMUNIT. SŁOMN."64. Dzwon „średni”, sygnowany „ME FECIT RESONANTE JOSEF ROSENBERSKI 1737”, ma na szyi inskrypcję wotywną: „HAEC CAMPANA PER ME MATH. SINOCHOSKI PROPRIA SUMPTU PIJA SUMPTU SUCURE POPULO", ujęta od dołu pasem ornamentu $\mathrm{w}$ formie stylizowanych liści. Najmniejszy instrument, $\mathrm{z}$ napisem: „ET VERBUM CARO FACTUM EST ET HABITAVIT IN NOBIS / ME FECIT JOSEF ROSENBERSKI 1737", dekoruje na szyi fryz ze stylizowanych liści, a na płaszczu plakieta - topór na pniu. Kabłąki korony ozdobione sa maskami65.

$Z$ roku 1739 pochodzi parament $z$ kościoła pw. św. Katarzyny w Przemykowie (pow. proszowicki), ulany we Wrocławiu przez Kacpra Koerberga. Na jego szyi widnieje majuskułowa inskrypcja: „AD M[AIOREM] D[EI] G[LORIAM] IMPENSIO: M[ARCINA] W[ALESZYNSKIEGO] K[ANONIKA] K[RAKOWSKIEGO] P[ROBOSZCZA] P[RZEMYKOWSKIEGO] IEZUS MARIA IOZEF”, a na pierścieniu odsercowym data odlewu i sygnaturka mistrza („ANNO 1739 GOSS. MICH.”). Płaszcz zdobia herb Akademii Krakowskiej, grupa Ukrzyżowania oraz wizerunek św. Jana Kantego. Dekorację paramentu uzupełniaja dwa fryzy umieszczone na szyi: górny - wąski, $z$ ornamentem roślinnym, oraz dolny - szeroki utworzony ze zwisajacych liści akantu66.

64 Wzmiankowany w inskrypcji Jakub Widera był proboszczem w Słomnikach w latach 1706-1739. Por. J. W i ś n i e w s k i, Dekanat miechowski..., s. 221.

65 Ibidem, s. 220; Katalog zabytków, t. I, z. 8, s. 38; WUOZ w Krakowie, karty ewidencyjne zabytku ruchomego, oprac. K. Nowacka, 1972 r.

66 Katalog zabytków, t. I, z. 9, s. 75; CIP, t. I, z. 4, s. 164, nr 216; J. W i śniewski, Historyczny opis kościołów [...] w Pinczowskiem, Skalbmierskiem $i$ Wiślickiem..., s. 329. Karta tego zabytku (bez opisu), sporzadzona w $1971 \mathrm{r}$. przez B. i Z. Dolczewskich, przechowywana jest w WUOZ w Krakowie. 
Sprowadzony z Węgier ludwisarz Kacper Kramnitz, skąinąd nieznany, wykonał na zlecenie bożogrobców miechowskich dwa spiżowe dzwony $z$ lat 1749 i 1750 , zawieszone w wysokiej, sześciokondygnacyjnej wieży przy bazylice Grobu Bożego. Pierwszy z nich, o wadze 1900 funtów, został przelany pod koniec XIX w. $z$ fundacji ówczesnego prepozyta, ks. Józefa Kwiatkowskiego. Informuje o tym stosowny napis umieszczony na szyi („A. D. 1749 sub regimine Jacobi Radliński Praepositi gnalis infulati S. Thomae oris ordinis can. Regul. S. sml. Sepulchri Xti Dni fusum. Transfusum sub regimine Josephui Kwiatkowski praepositi, decani Miechoviensis can. et camerarii SS-mi Pontificis Leonis XIII"). Płaszcz dekoruje plakietka $z$ figura Matki Boskiej. Drugi instrument ma na szyi inskrypcję wotywną o treści: „Sub regimine Jacobi Radliński Praepositi generali, infulati et custodis Supulchri foran. Ad M. Dei, B. V. Mariae. A. D. 1750", a na płaszczu przedstawienia Matki Boskiej i Trójcy Świętej67.

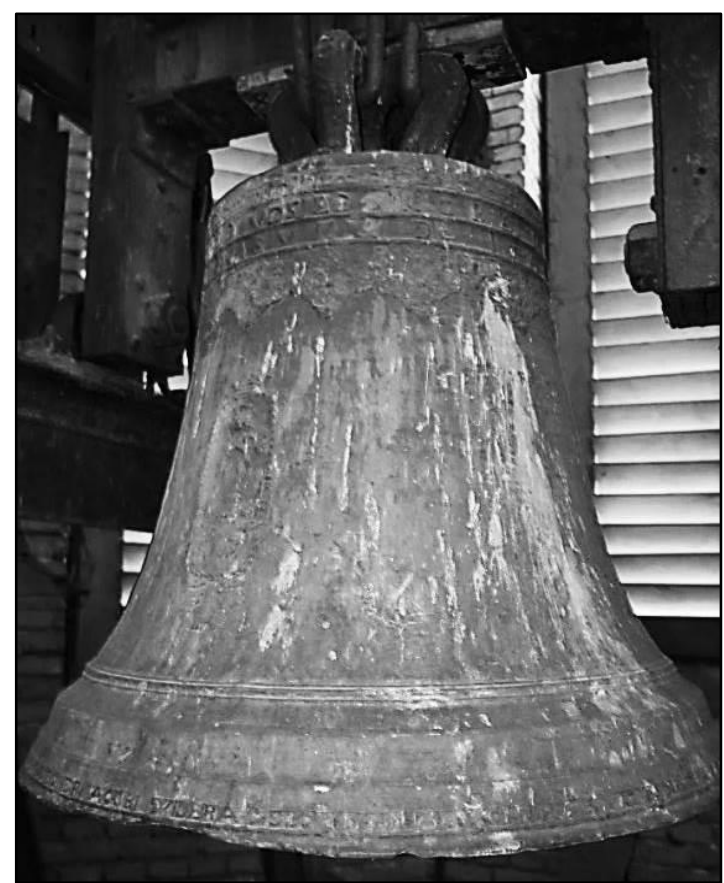

15. Słomniki, dzwon Józefa Rosenberskiego, pocz. XVIII w.

67 Cyt. za: J. Wiśniew ski, Dekanat miechowski..., s. 131. Por. też J. Kołaczkowski, op. cit., s. 400, 410; W. Siarkowski, op. cit., s. 49; Katalog zabytków, t. I, z. 8, s. 24; Z. P ę ckow s ki, Miechów. Studia z dziejów miasta i ziemi miechowskiej do roku 1914, Kraków 1967, s. 264, 266. 

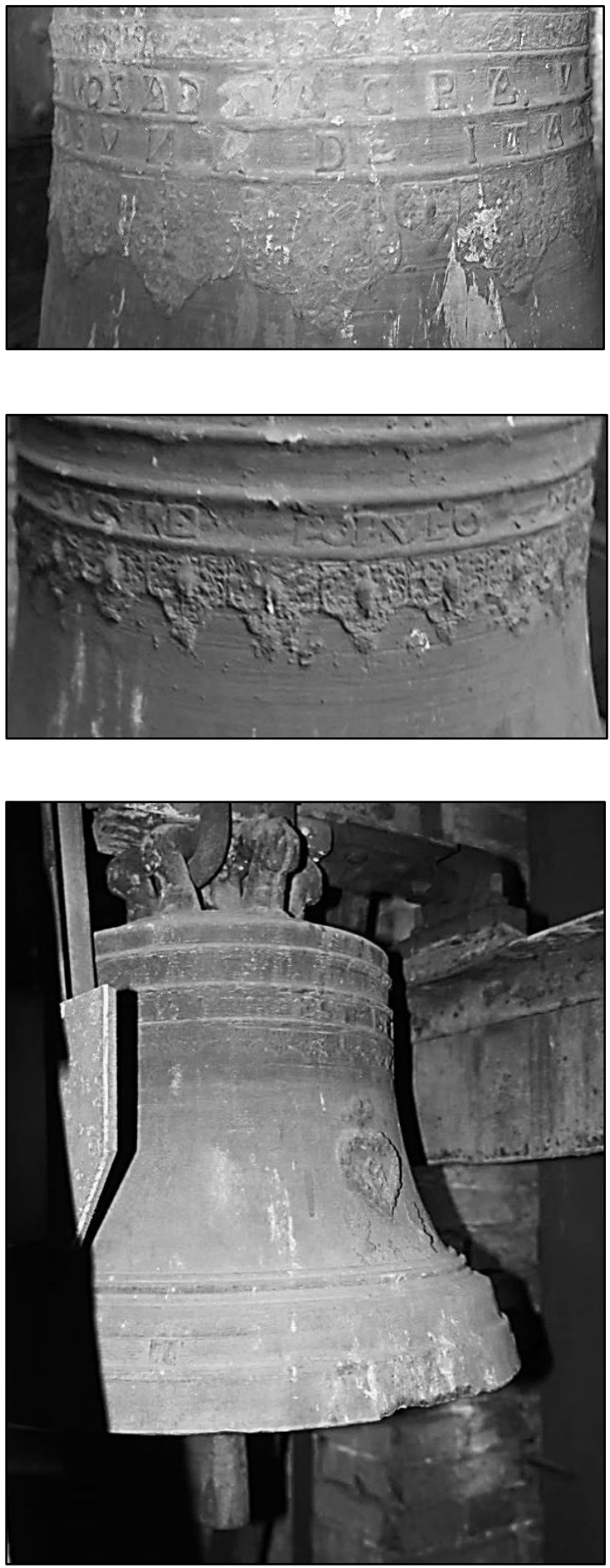

16. Słomniki, dzwon Józefa Rosenberskiego $z$ pocz. XVIII w., fragment inskrypcji i dekoracji w górnej partii płaszcza

17. Słomniki, górna część płaszcza dzwonu odlanego przez Józefa Rosenberskiego, 1737 r.

18. Słomniki, dzwon Józefa Rosenberskiego z $1737 \mathrm{r}$. 


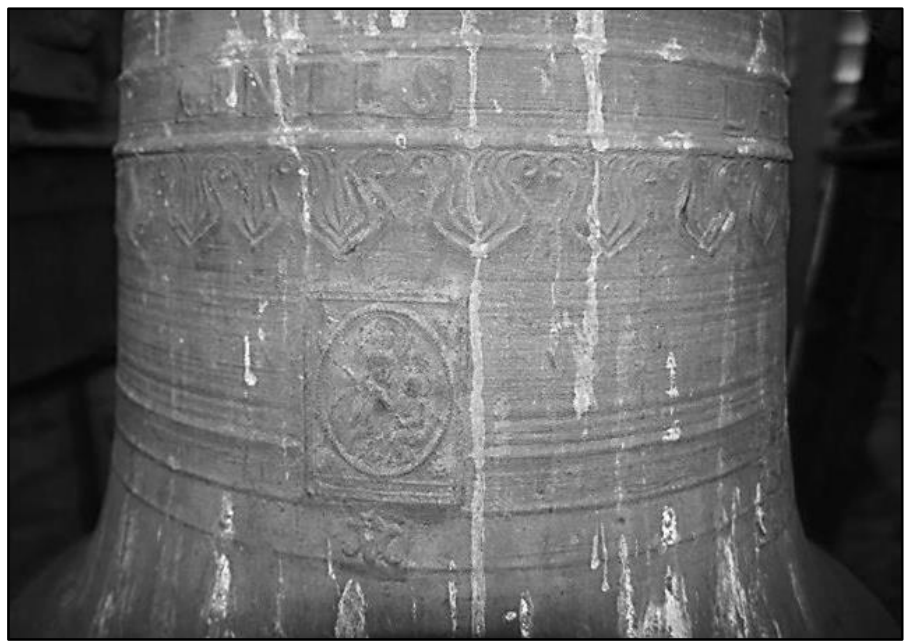

19. Słomniki, dzwon przelany przez Jana Zucha, 1874 r., fragment dekoracji płaszcza $z$ plakietką Matki Boskiej

Dwa dzwony $z$ Nasiechowic $w$ powiecie miechowskim, ulane w 1873 r., sa dziełem Jana Zucha $z$ Wiślicy. Na większym znajduje się majuskułowa inskrypcja w języku łacińskim: „VIVO VOCO MORTUOS PLANGO. HAEC CAMPANA SUMPTU PAROCHIANORUM NASIECHOVIENSIUM", wskazujaca na jego apotropaiczny charakter, a także sygnaturka: „LAŁ JAN ZUCH 1873”. Dekorację paramentu stanowi szeroki fryz roślinny umieszczony w górnej części płaszcza. Na szyi mniejszego instrumentu widnieje $z$ kolei napis: „DEO OPTIMO MAXIMO 1873 SUMPTU PAROCHIANORUM"68.

$Z$ tego samego warsztatu ludwisarskiego wyszedł dzwon $z$ kościoła parafialnego w Słomnikach (il 19), przelany w 1874 r. ze starszego instrumentu. Ma on koronę w formie sześciu kabłąków, ozdobiona płaskorzeźbionymi twarzami ludzkimi. Na szyi, pomiędzy dwoma wałkami, znajduje się sentencja zaczerpnięta $z$ Księgi Psalmów: „LAUDATE DOMINUM OMNES GENTES” (Ps 16,1 [17,1]), a poniżej płaska dekoracja w formie stylizowanych kwiatów. Na płaszczu, w owalu ujętym w prostokątna ramę, widnieje plakietka Matki Boskiej z Dzieciątkiem, pod nią zaś monogram imienia Maria. $Z$ prawej strony umieszczono napis $\mathrm{w}$ języku polskim (w trzech wierszach): „PRZELANY W ROKU 1874 KOSZTEM / PARAFIAN ZA

68 J. W i ś n i e w s ki, Dekanat miechowski..., s. 141; WUOZ w Krakowie, karty ewidencyjne zabytku ruchomego, oprac. I. Korczyńska-Baran, 2009 r. 
STARANIEM X. PAWŁA / SZCZEPAŃSKIEGO, PROBOSZCZA SŁOMNICKIEGO, FABRYKANT JAN ZUCH"69.

Pozostali twórcy znani nam sa tylko $z$ pojedynczych, sygnowanych wyrobów. Mały dzwon $z$ Uniejowa, odlany pierwotnie w 1625 r., przelany został w pracowni Andrzeja Fortuńskiego w Krakowie w 1863 r. Inskrypcja umieszczona na płaszczu informuje, że przetopienia dokonano $z$ inicjatywy Leona Mieroszewskiego, dzierżawcy miejscowego majątku, na cześć patrona świątyni - św. Wita ${ }^{70}$.

Ludwisarz warszawski Michał Petersilge, właściciel dużego zakładu o wielopokoleniowej tradycji71, w 1857 r. przelał instrument $z$ kościoła pw. św. Jana Ewangelisty w Pińczowie. Zabytek ten ma niewatpliwie bogata historię. Ufundowany przez biskupa krakowskiego Zbigniewa Oleśnickiego w pierwszej połowie wieku XV, został naprawiony w 1654 r. przez Benedykta Briota z Lotaryngii, staraniem przeora tamtejszego klasztoru (reformatów) Konstantego Jaroszowskiego, przetopiony ostatecznie za czasów biskupa Macieja Majerczaka. Przypominaja o tym napisy umieszczony na szyi dzwonu („Ad M. D. G. B. V. Mariae, S. Joan. Ewang. ac S. Pauli erem. honorem opus hoc primo a Zbigneo Oleśnicki fundatum, deinde a Gregorio et Anna Białozorskie sub priorata R. P. Constantini Jaroszewski vic. prof. A. D. 1654 reparatum labore Benedicti Briot Lotaringii”) oraz w środkowej części płaszcza, poniżej wizerunku Matki Boskiej z Dzieciątkiem („Administrat. Dioeces. Kielcenso - Crac. Mathia Majerczak, parocho Pińczov. Eusta. Havelski exprov. Ord. s. P. P. E. legatum R. D. Gregorii Suchański parochii loci exequente Francisci Maliński fecit Michael Petersilge Varsoviensis. A. D. 1857”). Oprócz figury Madonny parament zdobia jeszcze trzy inne plakietki ukazujące scenę Zmartwychwstania (czterech powalonych na ziemi żołnierzy, anioł siedzący na grobie, drugi unoszący się w powietrzu i postać Chrystusa Zmartwychwstałego), św. Józefa $z$ Panem Jezusem oraz nieustalonego świętego klęczącego przed krucyfiksem ( $z$ boku anioł niosący koronę) ${ }^{72}$.

69 J. W i śn i e w s ki, Dekanat miechowski..., s. 220.

70 Ibidem, s. 244; Z. J e dy nak, Dzieje Parafii Uniejów, Charsznica 2013, s. 45-46 (praca niepublikowana w zbiorach autora, za jej udostępnienie składam $\mathrm{w}$ tym miejscu podziękowanie Panu $Z$. Jedynakowi).

71 Odlewnia została założona w 1778 r. przez Jana Petersilgego, dziadka Michała. Michał przejąl ja po swym ojcu w $1847 \mathrm{r}$. Więcej na ten temat por. K. Gi erdziej ew s ki, op. cit., s. 128, 145-146.

72 Katalog zabytków, t. III, z. 9, s. 61; J. W i ś n i e w s k i, Historyczny opis kościołów [...] w Pinczowskiem, Skalbmierskiem i Wiślickiem..., s. 256, 258; J. Ko - 
Ostatni znany nam instrument opatrzony sygnaturka autorska to dzwon w Bejscach w powiecie kazimierskim, przetopiono $z$ kolei w słynnej warszawskiej ludwisarni Michała Antoniego Zwolińskiego (1846-1912) w roku 1878. Na jego szyi widnieje niezbyt szeroki fryz $z$ esowato zawijanych wici roślinnych, wzbogacony rozetkami. Poniżej znajdują się majuskułowa inskrypcja wotywna: „PRZELANY KOSZTEM DZIEDZICA I PARAFIAN", rok odlewu oraz sygnaturka ludwisarza, ujęte od dołu ornamentem kandelabrowym, komponowanym $z$ liści akantu. Dekorację dzwonu uzupełnia plakietka $z$ figura św. Mikołaja bpa - patrona świątyni, umieszczona w połowie wysokości płaszcza73.

Podsumowujac, na terenie diecezji kieleckiej zachowało się blisko 120 zabytkowych dzwonów, odlanych przed 1900 r., jednak zaledwie $41 \mathrm{z}$ nich, więc mniej niż połowa, to wyroby sygnowane imieniem i nazwiskiem ludwisarza oraz siedziba jego warsztatu. Instrumenty odlane $\mathrm{w} X \mathrm{XIV}-\mathrm{XV} \mathrm{w}$., przeważnie $\mathrm{z}$ napisem „O rex glorie veni cum pace", pozostaja dla nas całkowicie anonimowe. $Z$ wieku XVI ocalała tylko jedna sygnowana praca (dzwon $z$ Zagości), a $z$ kolejnego stulecia dwie - obie wykonane przez pracującego w Polsce Benedykta Briota $z$ Lotaryngii dla kościoła w Małogoszczu. Największą liczbę sygnowanych paramentów, bo aż 33, przynosi wiek XVIII. Wśród nich dominuja dzwony pochodzące ze słynnych w tym czasie ludwisarni gdańskich Wittwercków i Anthonych, a także $z$ nie mniej aktywnych odlewni krakowskich Weidnerów, Ignacego Huflauera czy Baltazara Ruszkowskiego. Z XIX w. zachowało się tylko kilka dzwonów opatrzonych sygnaturką mistrza, większość $z$ nich to przelewy starszych, zniszczonych zabytków, wykonane przez ludwisarzy warszawskich (M. Petersilge, M.A. Zwoliński) lub krakowskich (A. Fortuński).

Jeśli chodzi o inskrypcje umieszczane na dzwonach, to należy stwierdzić, że większość $z$ nich została wykonana w języku łacińskim, niektóre w języku polskim i łacińskim (instrumenty $z$ Bobina, Miechowa, Wodzisławia, Nasiechowic, Rembieszyc, Skalbmierza oraz Słomnik), a tylko w jednym przypadku - instrument w Bejscach z 1878 r. - zastosowano język ojczysty. Przeważaja napisy

ła c z k ow s ki, op. cit., s. 412; M. J u r e c ki, Ponidzie. W świętokrzyskim stepie, Kraków 2004, s. 146.

73 WUOZ w Kielcach, karta ewidencyjna zabytku ruchomego, oprac. Z. Wojtasik, 2000 r. Nieco inny układ inskrypcji podaje: J. Wiś n i e w s ki, Historyczny opis kościołów [...] w Pińczowskiem, Skalbmierskiem i Wiślickiem..., s. 256. 
o charakterze sentencjonalnym czy sentencjonalno-poświadczeniowym, choć niemało jest też inskrypcji wotywnych. Do najczęściej rozpowszechnionych napisów na dzwonach należą fragmenty Księgi Psalmów, w tym zwłaszcza Psalmu 112 (113), jak również Pieśni nad Pieśniami i Pierwszego Listu do Tymoteusza (tekst: „Soli Deo Gloria”).

$\mathrm{Na}$ zakończenie należy zaznaczyć, że przytoczona liczba 118 zabytków $z$ pewnością nie oddaje w pełni stanu faktycznego. Przeprowadzona kwerenda archiwalna, a przede wszystkim rozmowy $z$ pracującymi na parafiach księżmi ujawniły istnienie dzwonów nieodnotowanych dotychczas w literaturze przedmiotu, które np. trafiły do kościołów w wyniku rewindykacji po II wojnie światowej. Myślę, że takich niezinwentaryzowanych zabytków może być w terenie więcej. Zagadnienie dzwonów kościelnych uratowanych od rekwizycji wojennych na terenie diecezji kieleckiej wymaga dalszych, wnikliwych badań.

MAEGORZATA KARKOCHA

\section{Historic church bells in the region of the Diocese of Kielce. Workshops and craftsmen}

On the basis of available literature, materials collected in the Archives of the Diocese of Kielce, the Regional Office for the Protection of Monuments in Kielce and Krakow, as well as a result of field research conducted partly by the Author it can be concluded, that in the Diocese of Kielce there have been preserved, i.e. saved from requisitions and destruction of war, about 120 historic church bells. All of them date back to the period before 1900. Only 41 of those (fewer than half) bear a name and a surname of the bell-founder and a name of the location of the workshop. Bells cast in the $14^{\text {th }}$ and $15^{\text {th }}$ century, usually inscribed with the Latin words „O rex gloriae veni cum pace”, remain completely anonymous to us. Only one signed bell from the $16^{\text {th }}$ century is still extant in Zagość. There have also been preserved two bells dating back to the next century, both produced for the church in Małogoszcz by Benedict Briot from Lorraine, who worked in Poland. The largest number of signed specimens (as many as 33) come from the $18^{\text {th }}$ century. Among them there prevail bells from two famous bell foundries located in Gdańsk, namely the ones produced by the Wittwerck and Anthony families, and 
those coming from an equally active Kraków workshops belonging to the Weidner family, to Ignatius Huflauer and to Balthazar Ruszkowski (vel Roszkiewicz, Rośkiewicz). Only a few bells found in the $19^{\text {th }}$ century bear a signature of the producer. The majority of them were smelt from older, damaged specimens and were manufactured by bell founders located in Warsaw (M. Petersilge, M.A. Zwoliński) or in Kraków (A. Fortuński). 